\author{
Michał Jasztala $)^{*}$ \\ a) Military University of Technology / Wojskowa Akademia Techniczna \\ *Corresponding author / Autor korespondencyjny: michal.jasztal@wat.edu.pl
}

\title{
Testing the Process of Evacuation from the Passenger Aircraft with the Use of Computer Simulation
}

\section{Badanie procesu ewakuacji z samolotu pasażerskiego z wykorzystaniem symulacji komputerowej}

\begin{abstract}
Purpose: The main aim of the study was to investigate the possibility to use the Pathfinder simulation software to determine the duration of an evacuation and to plan its course for various scenarios of evacuation organisation, for specific profiles and behaviours of passengers and on-board personnel, and for a specific geometrical arrangement of the passenger cabin of a selected passenger aircraft. In addition, the paper discusses selected factors that affect the evacuation from the passenger aircraft.

The project and the methods: The Pathfinder software used in the research has the graphical interface to create an evacuation simulation model (2D and 3D) as well as tools to visualise the results. Pathfinder is based on artificial intelligence algorithms, in which each passenger has a number of individual features that can influence his/her movements and decisions during the simulation. The simulation of people's movement is determined by their profiles and behaviours, the parameters of which can be entered by means of probability distributions, which makes it possible to take into account the stochastic nature of the evacuation process.

Results: The Boeing 787 Dreamliner was selected for the study, for which six options for simulating the evacuation of 252 passengers and eight members of on-board personnel were conducted. The shortest evacuation time was achieved by changing the even distribution of the number of passengers to the individual emergency exits, thus avoiding congestions in sensitive areas of the passenger cabin. The increase in passengers' maximum speed has paradoxically increased evacuation times, as it has increased the intensity of passenger collisions. It was found that one of the key issues affecting the timing of an evacuation is the proper organisation of the evacuation by on-board personnel, who, by guiding passengers through the geometrically most advantageous passageways, results in the fastest possible evacuation. The simulations in variants five and six have achieved satisfactory evacuation times, which are within the emergency aircraft evacuation time limit required in a certification process.

Conclusions: The presented simulation models, the results obtained, and the wide range of possibilities of three-dimensional visualisation of research results give a rational basis for the use of Pathfinder software for testing the evacuation process and thus: for the usage in the aircraft design process, for preparing aircrafts for tests, for shaping evacuation procedures, for on-board personnel training and for air accident investigation.
\end{abstract}

Keywords: evacuation, passenger aircraft, computer simulation

Type of article: original scientific article

Received: 04.09.2020; Reviewed: 22.09.2020; Accepted: 21.10.2020;

Author's ORCID ID: M. Jasztal - 0000-0003-4133-2557;

Please cite as: SFT Vol. 56 Issue 2, 2020, pp. 22-39, https://doi.org/10.12845/sft.56.2.2020.2;

This is an open access article under the CC BY-SA 4.0 license (https://creativecommons.org/licenses/by-sa/4.0/).

\section{ABSTRAKT}

Cel: Głównym celem pracy było zbadanie możliwości wykorzystania oprogramowania symulacyjnego Pathfinder do wyznaczania czasu trwania ewakuacji i planowania jej przebiegu dla różnych scenariuszy organizacji ewakuacji, określonych profili i zachowań pasażerów i personelu pokładowego, oraz przyjętej aranżacji geometrycznej kabiny pasażerskiej wybranego samolotu pasażerskiego. Ponadto, w pracy omówione zostały wybrane czynniki, które mają wpływ na ewakuację z samolotu pasażerskiego.

Projekt i metody: Wykorzystane w badaniach oprogramowanie Pathfinder posiada graficzny interfejs do tworzenia modelu symulacyjnego ewakuacji (2D i 3D), jak również narzędzia służące do wizualizacji wyników. Pathfinder używa algorytmów z zakresu sztucznej inteligencji, w których każdy pasażer ma szereg indywidualnych cech osobowych mogących wpływać na jego ruchy i decyzje podczas symulacji. Symulacja poruszania się osób jest determinowana przez ich profile i zachowania, których parametry można wprowadzać za pomocą rozkładów prawdopodobieństwa, co daje możliwość uwzględnienia stochastycznego charakteru procesu ewakuacji. 
Wyniki: Do badań wybrano samolot pasażerski Boeing 787 Dreamliner, dla którego prowadzono sześć wariantów symulacji ewakuacji 252 pasażerów oraz ośmiu osób personelu pokładowego. Najkrótszy czas ewakuacji został osiągnięty po zmianie równomiernego podziału liczby pasażerów skierowanych do poszczególnych wyjść ewakuacyjnych. Pozwoliło to uniknąć powstawania zatorów w newralgicznych miejscach kabiny pasażerskiej. Zwiększenie maksymalnej prędkości poruszania się pasażerów paradoksalnie wydłużyło czas ewakuacji, ponieważ pociągnęło za sobą także wzrost liczby kolizji pasażerów. Stwierdzono, iż jedną z kluczowych kwestii wpływających na czas ewakuacji jest jej właściwa organizacja przez personel pokładowy, który kieruje pasażerów przez najkorzystniejsze geometrycznie przejścia. Symulacje w wariancie piątym i szóstym pozwoliły uzyskać zadowalające czasy ewakuacji, mieszczące się w wymaganym w procesie certyfikacji czasie awaryjnego opuszczenia samolotu.

Wnioski: Przedstawione modele symulacyjne, uzyskane rezultaty oraz szerokie możliwości w zakresie trójwymiarowych wizualizacji wyników badań dają racjonalne podstawy do wykorzystania oprogramowania Pathfinder do badania procesu ewakuacji, a przez to: wykorzystania go w procesie projektowania samolotów oraz przygotowywania ich do badań testowych, kształtowania procedur ewakuacyjnych, szkoleń personelu pokładowego oraz badania wypadków lotniczych.

Słowa kluczowe: ewakuacja, samolot pasażerski, symulacja komputerowa

Typ artykułu: oryginalny artykuł naukowy

Przyjęty: 04.09.2020; Zrecenzowany: 22.09.2020; Zaakceptowany: 21.10.2020;

Identyfikator ORCID autora: M. Jasztal - 0000-0003-4133-2557;

Proszę cytować: SFT Vol. 56 Issue 2, 2020, pp. 22-39, https://doi.org/10.12845/sft.56.2.2020.2;

Artykuł udostępniany na licencji CC BY-SA 4.0 (https://creativecommons.org/licenses/by-sa/4.0/).

\section{Introduction}

Despite ensuring a high level of air transport security, air accidents and catastrophes, in which it is necessary to evacuate passengers and air personnel, still occur. In addition, the restrictions on access to the cockpit, implemented in recent years as a result of the terrorist threat, and the increasing amount of baggage allowed in the passenger cabin are increasingly challenging for on-board personnel in an emergency situation [1-2].

Even in purely catastrophic circumstances, such as fire or hull fracture, a high level of passengers' survival can be achieved. However, the results of many accidents and incidents over the years have revealed problems with the efficiency and sufficiency of procedures and the training of flight crew and on-board personnel. The sooner the evacuation is initiated and effectively carried out, the more the number of casualties and deaths will be reduced [1-3].

This paper discusses the key factors, both positive and negative, that can affect an evacuation, taking into account the specific of construction and material characteristics of the equipment items and the geometric parameters of the passenger space, rescue equipment, requirements and procedures and the relevant results of air accident investigations. The main aim of the study was to investigate the possibility to use the Pathfinder simulation software to determine the duration of an evacuation and to plan its course for various scenarios of evacuation organisation, for specific profiles and behaviours of passengers and for a specific geometrical arrangement of the passenger cabin of a selected passenger aircraft Boeing 787 Dreamliner. It should be stressed that the Pathfinder software is the tool used to simulate the evacuation of people from various types of objects, as opposed to highly specialised simulation software such as airEXODUS, which is designed exclusively for testing the processes of aircraft emergency abandonment [4-7], [25].

\section{Wprowadzenie}

Pomimo zapewnienia wysokiego poziomu bezpieczeństwa transportu lotniczego, wypadki oraz katastrofy lotnicze, w których występuje konieczność ewakuacji pasażerów i personelu lotniczego, nadal mają miejsce. Dodatkowo wprowadzane w ostatnich latach na skutek zagrożenia terrorystycznego ograniczenia w dostępie do kabiny pilotów oraz rosnąca ilość dozwolonego bagażu w kabinie pasażerskiej stanowią coraz większe wyzwanie dla personelu pokładowego podczas działania w sytuacji awaryjnej [1-2].

Nawet w czysto katastroficznych okolicznościach, takich jak pożar lub pęknięcie kadłuba, wysoki poziom przeżywalności pasażerów jest możliwy do osiągnięcia. Jednakże rezultaty wielu wypadków oraz incydentów na przestrzeni lat ujawniły problemy z efektywnością i wystarczalnością procedur oraz ze stopniem wyszkolenia personelu lotniczego i pokładowego. Im szybciej ewakuacja jest zainicjowana i efektywniej przeprowadzona, tym mniejsza będzie liczba poszkodowanych i ofiar śmiertelnych [1-3].

W niniejszym artykule omówiono kluczowe czynniki wpływające na przebieg ewakuacji (zarówno pozytywne, jak i negatywne), uwzględniając: specyfikę budowy i charakterystyki materiałów elementów wyposażenia oraz parametry geometryczne przestrzeni pasażerskiej, wyposażenie ratownicze, kwestię wymagań i procedur oraz istotne wyniki badań wypadków lotniczych. W pracy podjęto się zadania sprawdzenia możliwości wykorzystania oprogramowania symulacyjnego Pathfinder do badania czasu trwania ewakuacji i planowania jej przebiegu dla różnych scenariuszy organizacji ewakuacji, określonych profili i zachowań pasażerów oraz przyjętej aranżacji geometrycznej kabiny pasażerskiej wybranego samolotu pasażerskiego Boeing 787 Dreamliner. Należy podkreślić, iż oprogramowanie Pathfinder jest narzędziem wykorzystywanym do symulacji ewakuacji osób z różnego rodzaju obiektów - w odróżnieniu od wysoko wyspecjalizowanego oprogramowania symulacyjnego, jak np. airEXODUS, które jest przeznaczone wyłącznie do badania procesów awaryjnego opuszczania statków powietrznych [4-7], [25]. 


\section{Selected issues of passenger aircraft evacuation}

Improvements in passenger and crew survival are being made by aviation authorities, aircraft manufacturers and flight operators. They relate to many very important problems. Despite the fact that our knowledge is based on air accidents, which often took place many years ago, these events are of great practical significance and have directly affected aviation authorities and other entities in terms of improving regulations, requirements and taking actions such as [8-13]:

- conducting endurance dynamic tests for seats and implementing criteria and limit values for injuries of passengers and crew;

- the use of non-flammable materials for the interior of the aircraft;

- use of thermal and acoustic insulation and conducting fire propagation tests;

- the use of materials emitting small amounts of heat and smoke during a fire and conducting tests in this area;

- the use of smoke detectors and fire-fighting systems in the passenger and luggage compartment, including additional smoke detectors and automatic fire extinguishers for waste bins;

- implementation of the escape route lighting near the cabin floor;

- the assembly of equipment to ensure safe breathing for passengers and crew;

- usage of specially designed and tested emergency exits and gangways (e.g.: emergency gangways with thermal reflective protection);

- the use of regular emergency training for flight crew and on-board personnel (Crew Resource Management CRM);

- implementation of checklists for flight crew and on-board personnel in the event of evacuation;

- implementation of restrictions on air passengers as regards occupying seats in the vicinity of emergency exits;

- training of air passengers in emergency behaviour before each take-off.

The majority of accidents of linear passenger aircraft, i.e. about $90 \%$ (according to the ETSC - European Transport Safety Council) are categorised as "survivable" [14]. The term "survivable accident" is defined as an accident, in which the forces acting on passengers do not exceed the limits of tolerance of the human body, including in terms of the rate at which they develop [15]. In addition, in this category of accidents, the structure of the passenger compartment shall remain intact to such an extent that a nominal passenger space is provided at all times during the accident and evacuation. Therefore, the occurrence of the vast majority of "survivable" accidents causes that it is the ability of passengers to evacuate and the abilities of the crew to initiate and manage the evacuation that determines the extent of the consequences of individual air accidents [14]

The evacuation equipment of passenger aircraft is constantly being improved. For example, there are facilities in assistance

\section{Wybrane zagadnienia ewakuacji samolotów pasażerskich}

Usprawnienia w zakresie zapewnienia przeżywalności pasażerów i załogi podejmowane są przez władze lotnicze, producentów samolotów oraz operatorów lotniczych. Dotyczą one wielu bardzo istotnych problemów. Pomimo tego, że nasza wiedza jest oparta na wypadkach lotniczych, które często miały miejsce wiele lat temu, to zdarzenia te mają duże znaczenie praktyczne i bezpośrednio wpłynęły na władze lotnicze i inne podmioty w zakresie poprawy regulacji, wymagań i podjęcia działań, takich jak [8-13]:

- prowadzenie wytrzymałościowych testów dynamicznych dla foteli oraz wprowadzenie kryteriów i dopuszczalnych wartości uszkodzeń ciała pasażerów i załogi;

- stosowanie materiałów niepalnych do wyposażenia wnętrza samolotu;

- stosowanie izolacji termicznej oraz akustycznej, a także prowadzenie testów propagacji pożaru;

- stosowanie materiałów wydzielających małe ilości ciepła i dymu podczas pożaru oraz prowadzenie testów w tym zakresie;

- stosowanie detektorów dymu oraz instalacji przeciwpożarowej w przedziale pasażerskim i bagażowym, w tym dodatkowych detektorów dymu oraz automatycznych gaśnic pojemników na śmieci;

- wprowadzenie oświetlenia ścieżki ewakuacji w pobliżu podłogi kabiny;

- wprowadzenie wyposażenia zapewniającego bezpieczne oddychanie dla pasażerów i załogi samolotu;

- stosowanie specjalnie zaprojektowanych oraz przetestowanych wyjść oraz trapów ewakuacyjnych (np. trapów ewakuacyjnych z refleksyjną ochroną termiczną);

- stosowanie regularnych treningów personelu lotniczego i pokładowego w zakresie sytuacji awaryjnych (z ang. Crew Resource Management, CRM);

- wprowadzenie procedur (z ang. checklists) dla personelu lotniczego i pokładowego na wypadek ewakuacji;

- wprowadzenie ograniczeń dla pasażerów samolotu w odniesieniu do zajmowania miejsc w pobliżu wyjść awaryjnych;

- prowadzenie przed każdym startem szkolenia pasażerów samolotu na temat zachowań obowiązujących w sytuacji awaryjnej.

Większość wypadków liniowych samolotów pasażerskich, tj. około 90\% (wg ETSC - European Transport Safety Council), jest kategoryzowanych jako survivable, czyli możliwych do przeżycia [14]. Termin survivable accident jest definiowany jako wypadek, w którym siły działające na pasażerów nie przekraczają granicy tolerancji organizmu człowieka, również w zakresie szybkości ich narastania [15]. Dodatkowo, w tej kategorii wypadków struktura kabiny pasażerskiej pozostaje nieuszkodzona w takim stopniu, aby w każdym momencie przebiegu wypadku i ewakuacji była zapewniona nominalna przestrzeń przeznaczona dla pasażerów. Stąd też występowanie większej liczby wypadków „możliwych do przeżycia” powoduje, że to właśnie zdolność pasażerów do ewakuacji oraz umiejętności załogi do zainicjowania tego procesu i zarządzania nim decydują o rozmiarze skutków poszczególnych wypadków lotniczych [14]. 
systems for opening aircraft doors and developing escape gangways, which is particularly important for large aircraft, where these operations would require a lot of force and take too long to complete manually. Many improvements have also been made to the so-called Type III emergency exits, through which evacuation to the aircraft wing is carried out. The technical solutions of evacuation gangways, which are currently fully automatic, are constantly being developed. Equally important is the proper illumination of the escape route, which is why systems are installed to illuminate the escape route (close to the cabin floor) with lighting and marking of the escape doors to facilitate movement in the right direction in darkness and in dense smoke. The emergency lighting system also has elements to illuminate the area outside the aircraft, especially the areas to which passengers and crew are directly evacuated.

To sum up, it can be said that the highest possible survival rate for passengers and crew in air accidents is due to constantly improving regulations in the area of airworthiness and operational requirements, improving aircraft design in the area of emergency evacuation systems and their technical reliability, and due to constantly improving procedures and training for flight crew and on-board personnel. How important it is for the smooth implementation of evacuation procedures can be confirmed by the "Fire Safety Engineering Group" (FSEG) at the Univeristy of Greenwich, published in January 2017, which concerns an analysis of the Manchester accident of August 22, 1985, by Boeing 737-200 operated by British Airtours [16]. The analysis of the accident and the simulations carried out showed that: one minute's delay in opening the aircraft's front escape door resulted in the death of 48 passengers, while a 30 -second delay in opening the escape door to the aircraft wing resulted in the death of 20 passengers. If all emergency exits had been opened at the time set in the certification tests, all passengers and crew would have been effectively evacuated [16]

The number and deployment of the on-board personnel on the aircraft board is also extremely important, which has a direct influence on evacuation procedures. On-board personnel is needed not only to open emergency exits during the evacuation, but also to keep the emergency doors closed in case of emergency, i.e. fire outside the aircraft. This important issue in personnel operations is not covered by the airworthiness criteria. Many aviation organisations have requirements based on the "one in 50" rule (one-per-50), which requires one member of on-board personnel for every fifty passengers, or a corresponding fraction of 50 passenger seats installed on board, irrespective of the actual number of passengers taken on board on a given flight [8-10]. For aircrafts with 19 or fewer number of passenger seats there are no requirements for the number of on-board personnel. In such a case, where passengers themselves may be in the situation when they have to open emergency exits on their own and start the evacuation process without the involvement of the on-board personnel, then the effectiveness of the passenger instruction provided by the on-board personnel becomes extremely important. The requirements of certain air carriers provide that, for each Type A emergency exit (exit with appropriate minimum dimensions at passenger floor level) for twin-aisle aircrafts (with two
Sprzęt ewakuacyjny samolotów pasażerskich poddawany jest ciągłemu doskonaleniu. Przykładem mogą być udogodnienia w zakresie układów wspomagających otwieranie drzwi samolotu oraz rozwijanie trapów ewakuacyjnych, co jest szczególnie istotne dla dużych statków powietrznych, w których wykonanie tych operacji ręcznie wymagałoby użycia znacznej siły i zajmowałoby zbyt dużo czasu. Wiele usprawnień zostało poczynionych również w obszarze wyjść awaryjnych tzw. typu III, przez które prowadzona jest ewakuacja na skrzydło samolotu. Ciągle rozwijane są coraz to doskonalsze rozwiązania techniczne trapów ewakuacyjnych, które w chwili obecnej są urządzeniami w pełni automatycznymi. Równie ważną kwestią jest właściwe oświetlenie drogi ewakuacji, stąd też praktyka instalowania systemów oświetlenia ścieżki ewakuacji (w pobliżu podłogi kabiny) wraz z oświetleniem i oznaczeniem drzwi ewakuacyjnych. Rozwiązanie to stanowi znaczne ułatwienie w poruszaniu się we właściwym kierunku podczas ciemności oraz przy obecności gęstego dymu. System oświetlenia awaryjnego posiada również elementy oświetlenia obszaru na zewnątrz samolotu, szczególnie powierzchni, na którą bezpośrednio ewakuowani są pasażerowie oraz załoga.

Podsumowując, można stwierdzić, iż możliwie wysoka przeżywalność pasażerów oraz załogi w wypadkach lotniczych jest zasługą ciągle udoskonalanych regulacji w obszarze zdatności do lotu oraz wymagań operacyjnych, ulepszania konstrukcji statków powietrznych w zakresie systemów awaryjnej ewakuacji oraz ich niezawodności technicznej, a także nieustannie dopracowywanych procedur i szkoleń załogi lotniczej i pokładowej. 0 tym, jak bardzo istotne jest sprawne realizowanie procedur ewakuacji, może świadczyć analiza wypadku samolotu Boeing 737-200 linii lotniczych British Airtours z dnia 22 sierpnia 1985 roku, opracowana przez zespół Fire Safety Engineering Group (FSEG) z Uniwersytetu Greenwich [16]. W wyniku analizy wypadku oraz przeprowadzonych symulacji stwierdzono, że jedna minuta opóźnienia w otwarciu przednich drzwi ewakuacyjnych samolotu przyczyniła się do śmierci 48 pasażerów, natomiast 30-sekundowe opóźnienie w otwarciu drzwi ewakuacyjnych na skrzydło samolotu przyczyniło się do śmierci 20 pasażerów. Jeżeli wszystkie wyjścia awaryjne zostałyby otwarte w czasie ustalonym w badaniach certyfikacyjnych, to wszyscy pasażerowie i załoga zostaliby skutecznie ewakuowani [16].

Niezwykle istotna jest również liczba i rozmieszczenie personelu pokładowego na pokładzie samolotu - ma to bezpośredni wpływ na procedury ewakuacji. Do obowiązków personelu pokładowego należy nie tylko otwieranie wyjść awaryjnych podczas ewakuacji, ale również utrzymanie zamkniętych drzwi awaryjnych $w$ sytuacji zagrożenia, tj. pożaru na zewnątrz samolotu. To istotne działanie personelu nie jest ujęte $w$ kryteriach zdatności do lotu. Wiele organizacji lotniczych bazuje na regule "jeden na 50" (ang. one-per-50), która stawia wymóg zapewnienia na pokładzie jednego członka personelu pokładowego na każdych pięćdziesięciu pasażerów, lub pięćdziesiąt foteli pasażerskich zainstalowanych na pokładzie, bez względu na faktyczną liczbę pasażerów zabranych na pokład w danym locie [8-10]. Dla samolotów, w których zainstalowano 19 lub mniejszą liczbę foteli pasażerskich, nie ma wymagań odnośnie do liczebności personelu pokładowego. Oznacza to, że sami pasażerowie - bez udziału personelu pokładowego - mogą znaleźć się w sytuacji konieczności samodzielnego otwarcia wyjść awaryjnych i rozpoczęcia procesu ewakuacji. Wówczas efektywność 
corridors between the rows of seats) one on-board personnel member, who is required to take a seat near the emergency exit during take-off and landing, is dedicated. For example, for double corridor wide-bodied passenger aircrafts, which are certified for 440 passenger seats, four pairs of Type A emergency exits, the presence of nine on-board personnel members is required, but the subsequent arrangement of the deck with a first class or "business class" compartment inevitably reduces the total number of seats. As a consequence, fewer seats, e.g: 300 according to the "one-per-50" rule will cause that only six crew members will be required. This may result in a situation where not all A-type emergency exits are "manned" by a member of the on-board personnel. In such a situation the air operator should carry out a risk analysis for the applicable evacuation procedure. However, in many cases, aviation organisations (e.g. EASA) find it unacceptable that one on-board personnel member would "oversee" an evacuation through a pair of evacuation exits and recommend the presence of a on-board personnel member at each exit. There is, of course, a classification of evacuation exits according to their types, which gives the minimum dimensions of the individual exits as well as the expected number of passengers that can be evacuated by the individual types of exits.

Another rule adopted in the late 1980s by the FAA (US Federal Aviation Administration) was the " 60 foot" rule, which stipulated that no pair of escape doors at passenger base level must be more than 60 feet $(18.288 \mathrm{~m})$ apart. This rule also meant that no passenger should sit further than 30 feet $(9.144 \mathrm{~m})$ from the nearest emergency exit [8-10].

It was very important from the point of view of aircraft emergency abandonment to formulate requirements for evacuation gangways, which depend on the type of evacuation exit in which they are installed. In short, these requirements are as follows [8-10]:

- any emergency exit which is installed at a height of $1.8 \mathrm{~m}$ (from the ground level of the aircraft at a standstill with its landing gear unfolded) must have an evacuation gangway to allow the evacuation of passengers and crew from the aircraft to ground level;

- the evacuation gangway must be automatically deployed and activated by the crew or passengers from inside the aircraft;

- the evacuation gangway must be fully expanded and ready for evacuation within 10 seconds of its activation (activation of the evacuation exit);

- the evacuation gangway should be long enough to reach the ground level when unfolded, and should be a self-supporting structure ensuring safe evacuation (even in case of damage to the aircraft landing gear);

- the evacuation gangway must be capable of being unfolded and provide stable evacuation in winds up to $46 \mathrm{~km} / \mathrm{h}$ (25 knots) blowing from the most unfavourable direction with the aircraft engines idling;

- evacuation gangways in wide-bodied aircraft, with two corridors between rows of seats, are made as gangways with two parallel escape lanes;

- due to possible injuries and delays during evacuation from emergency exits located at a height of $1.8 \mathrm{~m}$ and below, instruktażu pasażerów wykonanego przez personel lotniczy zyskuje ogromne znaczenie. Wymogi niektórych przewoźników lotniczych przewidują, że dla każdego wyjścia awaryjnego typu A (wyjście o odpowiednich wymiarach minimalnych na poziomie podłogi pokładu pasażerskiego) dla samolotów twin-aisle (z dwoma korytarzami pomiędzy rzędami siedzeń) dedykowany jest jeden członek załogi, zobowiązany zająć miejsce w pobliżu wyjścia awaryjnego podczas startu i lądowania. Przykładowo, dla samolotów pasażerskich szerokokadłubowych z podwójnym korytarzem, które są certyfikowane dla 440 foteli pasażerskich, czterech par wyjść awaryjnych typu A, wymagana jest obecność dziewięciu osób personelu pokładowego. Jednakże późniejsza aranżacja pokładu zakładająca istnienie przedziału pierwszej klasy lub business class powoduje nieuniknioną redukcję całkowitej liczby foteli. W konsekwencji mniejsza liczba foteli (np. 300 wg reguły one-per-50) spowoduje, iż wymaganych będzie jedynie sześciu członków załogi. Może to prowadzić do sytuacji, w której nie wszystkim wyjściom awaryjnym typu A będzie przypisany członek załogi pokładowej. W takiej sytuacji operator lotniczy powinien przeprowadzić analizę ryzyka dla obowiązującej procedury ewakuacyjnej. Jednakże $w$ wielu przypadkach organizacje lotnicze (np. EASA) uznają za niedopuszczalną sytuację, w której jeden członek załogi pokładowej miałby nadzorować ewakuację przebiegającą przez parę wyjść ewakuacyjnych - zalecają obecności członka załogi pokładowej przy każdym wyjściu. Oczywiście istnieje klasyfikacja wyjść ewakuacyjnych wg ich typów, w której podaje się zarówno minimalne wymiary poszczególnych wyjść, jak również przewidywaną liczbę pasażerów, którzy mogą zostać przez nie ewakuowani.

Kolejną regułą przyjętą pod koniec lat osiemdziesiątych przez FAA (Federal Aviation Administration USA) była reguła "60 stóp" (ang. 60 foot rule), która określała, że żadna para drzwi ewakuacyjnych na poziomie pokładu pasażerskiego nie może być oddalona od siebie o więcej niż 60 stóp (18,288 m). Precyzowała również, że żaden z pasażerów nie powinien siedzieć w odległości większej niż 30 stóp $(9,144 \mathrm{~m})$ od najbliższego wyjścia awaryjnego [8-10].

Bardzo istotne z punktu widzenia awaryjnego opuszczania samolotu było sformułowanie wymagań odnośnie trapów ewakuacyjnych. Zależą one od typu wyjścia ewakuacyjnego, w którym są zainstalowane. Pokrótce wymagania te można ująć w następujące punkty [8-10]:

- każde wyjście awaryjne, zainstalowane na wysokości $1,8 \mathrm{~m}$ (od poziomu gruntu dla samolotu będącego na postoju z rozłożonym podwoziem) musi posiadać trap ewakuacyjny umożliwiający ewakuację pasażerów i załogi z samolotu do poziomu gruntu;

- trap ewakuacyjny musi być rozkładany w sposób automatyczny i aktywowany przez załogę lub pasażerów z wnętrza samolotu;

- trap ewakuacyjny musi zostać w pełni rozwinięty i gotowy do ewakuacji w ciągu 10 sekund od czasu jego aktywacji (aktywacji wyjścia ewakuacyjnego);

- trap ewakuacyjny powinien mieć taką długość, aby w stanie rozłożonym dosięgał poziomu gruntu, stanowiąc konstrukcję samonośną, zapewniającą bezpieczną ewakuację (nawet w sytuacji uszkodzenia podwozia samolotu);

- trap ewakuacyjny musi dawać możliwość rozłożenia i zapewnienia stabilnej ewakuacji przy wietrze o prędkości 
the use of emergency gangways is also recommended;

- in the case when an aircraft lands on the water, double-track evacuation gangways may serve as liferafts, while narrower evacuation gangways serve as displacement chambers to facilitate the passengers' stay on the water surface (in some aircrafts, liferafts, unfolded from the inside of the aircraft fuselage, are also used).

Conducting the evacuation procedure from an aircraft requires very good preparation by the flight crew and on-board personnel. Therefore, there were recommendations that the training of the aircraft crew should take into account [17]:

- coordination of the crew's actions and their mutual communication;

- areas of passenger traffic management;

- diverting passengers from emergency exits, which cannot be used, to exits, through which they can be safely evacuated;

- problems of overcrowded evacuation exits;

- commands given by the crew during the evacuation;

- physical contact with passengers, which may be required to provide assistance after leaving the aircraft.

The requirement for the manufacturer to obtain certification of a given passenger aircraft in terms of evacuation requirements requires a practical test of such an evacuation taking into account at least the following conditions [8-10]:

- only 50 percent of emergency exits are available for usage in such a test;

- no participant in this test (including crew members) is aware of which emergency exits will be available for use before the test begins;

- the test is carried out with reduced lighting of the cabin;

- on-board luggage may be placed on escape routes (corridors between the seats);

- all test participants, i.e. passengers and also flight crew and on-board personnel, must be on the ground outside the aircraft within 90 seconds of starting the evacuation without any assistance from ground personnel.

The criteria, against which the manufacturer's evacuation tests are carried out, are analysed by the aviation organisations responsible for certification, for example: FAA (Federal Aviation Administration - USA) for Boeing, EASA (European Aviation Safety Agency) for Airbus, TCCA (Transport Canada Civil Aviation) for Bombardier and ANAC (Agencia Nacional de Aviação Civil - Brazil) for Embraer. Of course, the subject aircraft manufacturer's interest is to meet the evacuation requirements for the largest possible number of passenger seats with a certain number and type of emergency exits, as well as the most restrictive passenger cabin configuration. In order to enable, at the stage of aircraft interior design, the initial verification of the possibility to carry out an evacuation that meets the requirements in this extent, attempts are made to use simulation tools to perform this type of tests [4-7]. However, the need to carry out practical evacuation tests, that meet the above-mentioned criteria for pre-prepared variants of passenger cabin configuration and adopted evacuation procedures, remains unchanged. do 46 km/h (25 węzłów) wiejącego z najbardziej niekorzystnego kierunku, przy silnikach samolotu pracujących na biegu jałowym;

- trapy ewakuacyjne w samolotach szerokokadłubowych z dwoma korytarzami między rzędami foteli są wykonywane jako trapy z dwoma równoległymi torami ewakuacyjnymi;

- ze względu na możliwe urazy oraz opóźnienia podczas ewakuacji z wyjść ewakuacyjnych, umieszczonych na wysokości 1,8 $\mathrm{m}$ i poniżej, również zaleca się stosowanie trapów ewakuacyjnych;

- w przypadku wodowania samolotu trapy ewakuacyjne dwutorowe mogą służyć jako tratwy ratunkowe, natomiast węższe trapy ewakuacyjne służą, jako komory wypornościowe ułatwiające utrzymywanie się pasażerów na powierzchni wody (w niektórych samolotach stosowane są również tratwy ratunkowe rozkładane $z$ kadłuba samolotu).

Przeprowadzenie procedury ewakuacji ze statku powietrznego wymaga bardzo dobrego przygotowania personelu lotniczego oraz pokładowego. Stąd też powstały rekomendacje regulujące zakres treningu załogi samolotu. Powinien on uwzględniać [17]:

- koordynację działań załogi i jej wzajemną komunikację;

- obszary zarządzania ruchem pasażerów;

- przekierowanie pasażerów od wyjść ewakuacyjnych, które z różnych powodów muszą pozostać zamknięte, do wyjść, przez które można się bezpiecznie ewakuować;

- problemy nadmiernego zatłoczenia wyjść ewakuacyjnych;

- komendy podawane przez załogę podczas ewakuacji;

- fizyczny kontakt z pasażerami, który może być wymagany w celu udzielenia pomocy po opuszczeniu samolotu.

Wymóg uzyskania przez producenta certyfikacji danego samolotu pasażerskiego w aspekcie wymagań ewakuacji wymusza wykonanie praktycznego testu takiej ewakuacji, z uwzględnieniem poniższych warunków [8-10]:

- tylko 50 procent wyjść ewakuacyjnych jest dostępnych do wykorzystania w trakcie testu;

- żaden z uczestników testu (włączając w to członków załogi) nie został uprzedzony przed jego rozpoczęciem, które wyjścia ewakuacyjne będą możliwe do użycia;

- test jest realizowany przy zredukowanym oświetleniu kabiny;

- bagaże pokładowe mogą znaleźć się na drogach ewakuacji (korytarzach między fotelami);

- wszyscy uczestnicy testu, tj. pasażerowie oraz członkowie załogi latającej i pokładowej, muszą znaleźć się na ziemi poza samolotem w ciągu 90 sekund od chwili rozpoczęcia ewakuacji bez żadnej pomocy ze strony personelu naziemnego.

Kryteria, według których prowadzone są producenckie testy ewakuacji, są analizowane przez odpowiedzialne za certyfikacje organizacje lotnicze, takie jak: FAA (Federal Aviation Administration - USA) dla Boeinga, EASA (European Aviation Safety Agency) dla Airbusa, TCCA (Transport Canada Civil Aviation) dla Bombardiera oraz ANAC (Agencia Nacional de Aviação Civil - Brazil) dla Embraera. Oczywiście producent samolotu jest zainteresowany spełnieniem wymagań ewakuacji zarówno dla największej możliwej liczby foteli pasażerskich przy określonej liczbie i typie wyjść 
ewakuacyjnych, jak również przy najbardziej restrykcyjnej konfiguracji kabiny pasażerskiej. Aby na etapie projektowania wnętrza samolotu możliwe było wstępne sprawdzenie możliwości przeprowadzenia ewakuacji spełniającej wymagania w tym zakresie, podejmuje się próby wykorzystania narzędzi symulacyjnych do wykonania tego typu testów [4-7]. Niezmienną pozostaje jednakże konieczność przeprowadzenia testów praktycznej ewakuacji spełniającej wyżej wymienione kryteria dla wstępnie przygotowanych wariantów konfiguracji kabiny pasażerskiej oraz przyjętych procedur ewakuacji.

\section{Usage of the Pathfinder software application to simulate evacuations of passengers from an aircraft}

Pathfinder is a simulator for evacuation of people, setting the time of the evacuation and many other parameters related to the evacuation. The software application has a graphical interface to create an evacuation simulation model, both in 2D and $3 \mathrm{D}$ environments, as well as tools to visualize the results [25]. Pathfinder uses artificial intelligence algorithms, in which each defined user has a number of individual features that can influence his/her movements and decisions during the simulation. The person, who moves during the evacuation, takes "virtual consideration" of the whole surrounding environment, i.e. the geometry of the object and the behaviours of the people around that person, in each time step of the simulation. Simulation of people's movement is determined by their profiles and behaviours. The profile of a person is defined by the speed of movement of the person, their dimensions (e.g. diameter of the cylinder surrounding the figure), response time to a collision with elements of the cabin or other passengers and a number of additional specific parameters. People with a specific profile have an assigned avatar appearance used during 3D visualization. In turn, people's behaviours determine the sequence of actions during the simulation, i.e. going to the nearest or indicated exit, moving to the indicated place, stopping and waiting, and leaving the object as the last sequence for each behaviour. The characteristics given to individuals or groups of individuals (e.g. speed of movement or width of arms) may be expressed by fixed values as well as by the probability distribution of the variable. It is possible to choose the type of probability distribution and its parameters, e.g. for a normal distribution these are: expected value and standard deviation as well as maximum and minimum acceptable values. Due to the possibility to enter parameters of people's profiles by means of probability distributions, the software used gives the possibility to take into account the stochastic nature of the evacuation process [25].

The software enables simulation based on two types of mathematical models of movement of people in the Pathfinder software application. The first of these so called "variable-control" assumes that for individual models of evacuating people the momentary directions of movement are chosen in individual simulation steps so that their individual evacuation time is as short as possible (i.e. in each subsequent time step evacuating people choose the most advantageous escape route for themselves,

\section{Wykorzystanie oprogramowania Pathfinder do symulacji ewakuacji pasażerów z samolotu}

Pathfinder jest symulatorem ewakuacji osób, wyznaczania czasu jej przeprowadzenia oraz wielu innych parametrów związanych z ewakuacją. Program posiada zarówno graficzny interfejs do tworzenia modelu symulacyjnego ewakuacji w środowisku 2D i 3D, jak i narzędzia służące do wizualizacji wyników [25]. Pathfinder używa algorytmów z zakresu sztucznej inteligencji, w których każdy zdefiniowany użytkownik ma szereg indywidualnych cech osobowości mogących wpływać na jego ruchy i decyzje podczas symulacji. Osoba, która przemieszcza się podczas ewakuacji, w każdym kroku czasowym symulacji „bierze wirtualnie pod uwagę" całe otaczające go środowisko tj. geometrię obiektu i zachowania otaczających go ludzi. Symulacja poruszania się osób jest determinowana przez ich profile i zachowania. Profil osoby definiowany jest przez prędkość jej poruszania się, wymiary (np. średnica walca okalającego postać), czas reakcji na kolizję z elementami kabiny lub innymi pasażerami oraz szeregiem dodatkowych parametrów szczegółowych. Osoby o określonym profilu posiadają przypisany im wygląd zewnętrzny awatara, który jest wykorzystywany podczas wizualizacji 3D. Z kolei zachowania osób określają sekwencję akcji w trakcie trwania symulacji, tj. kierowanie się do najbliższego lub wskazanego wyjścia, przejście we wskazane miejsce, postój i oczekiwanie oraz wyjście z obiektu jako ostatnia sekwencja dla każdego zachowania. Zadawane charakterystyki poszczególnych osób lub grup osób (np. prędkość poruszania się czy też szerokość ramion) mogą być wyrażane zarówno wielkościami stałymi, jak również za pomocą rozkładu prawdopodobieństwa danej zmiennej. Istnieje możliwość wyboru typu rozkładu prawdopodobieństwa oraz jego parametrów, np. dla rozkładu normalnego są to: wartość oczekiwana oraz odchylenie standardowe, a także dopuszczalne wielkości maksymalne i minimalne. Dzięki możliwości wprowadzania parametrów profili osób za pomocą rozkładów prawdopodobieństwa wykorzystywane oprogramowanie daje możliwość uwzględnienia stochastycznego charakteru procesu ewakuacji [25].

Oprogramowanie daje możliwość przeprowadzenia symulacji w oparciu o dwa rodzaje modeli matematycznych poruszania się osób w programie Pathfinder. Pierwszy z nich, tzw. zmienno-sterujący, zakłada, iż dla poszczególnych modeli ewakuujących się ludzi wybierane są w poszczególnych krokach symulacji chwilowe kierunki poruszania się tak, aby ich indywidualny czas ewakuacji był jak najkrótszy (tj. w każdym kolejnym kroku czasowym ewakuujący się ludzie wybierają najkorzystniejszą dla siebie drogę 
unless a specific escape route or other behaviour is imposed on them). This model takes into account the interactions that occur with other people, elements of infrastructure, the inertia of reactions and all the set parameters of profiles and behaviours of evacuating people. Pathfinder also contains an alternative model of crowd movement based on empirical equations described in the literature, i.e. the Society of Fire Protection Engineers Handbook (SFPE Handbook) guidelines [23]. This simplified model of movement of people allows relatively quick determination of the evacuation time even for a large model of building complex with a significant number of evacuated people.

The results of the simulation - apart from 3D visualisation of its course and its duration - include charts of the density of people on a given area, the speed of people flowing through individual exits, the ways of movement of individual people together with the detection of congestions and collisions.

For the tests presented in this paper, it was decided to select the Boeing 787 Dreamliner as the facility for which the evacuations of 252 passengers on board and eight members of on-board personnel were simulated. It was assumed that the arrangement of the passenger cabin space was made as in Figure 1 [24] ucieczki, o ile nie została im narzucona określona droga ewakuacji lub inne zachowania). Model ten uwzględnia występowanie interakcji z innymi osobami, elementami infrastruktury, bezwładność reakcji oraz wszystkie zadane parametry profili i zachowań ewakuujących się ludzi. Pathfinder zawiera również alternatywny model poruszania się tłumu, bazujący na równaniach empirycznych opisanych w literaturze przedmiotu, tj. wytycznych SFPE Handbook (Society of Fire Protection Engineers Handbook) [23]. Ten uproszczony model poruszania się osób pozwala na względnie szybkie określenie czasu ewakuacji nawet dla dużego modelu kompleksu budynków ze znaczną liczbą ewakuowanych osób.

Wyniki symulacji - oprócz wizualizacji 3D, jej przebiegu oraz czasu jej trwania - zawierają wykresy gęstości przebywania ludzi na określonej powierzchni, prędkości przepływu ludzi przez poszczególne wyjścia, drogi poruszania się poszczególnych osób wraz z wykrywaniem zatorów i kolizji.

Do badań przedstawionych w niniejszym artykule wybrano samolot pasażerski Boeing 787 Dreamliner jako obiekt, dla którego zostały prowadzone symulacje ewakuacji 252 pasażerów znajdujących się na jego pokładzie oraz ośmiu osób personelu pokładowego. Przyjęto, że aranżacja przestrzeni kabiny pasażerskiej została wykonana jak na rycinie 1 [24].

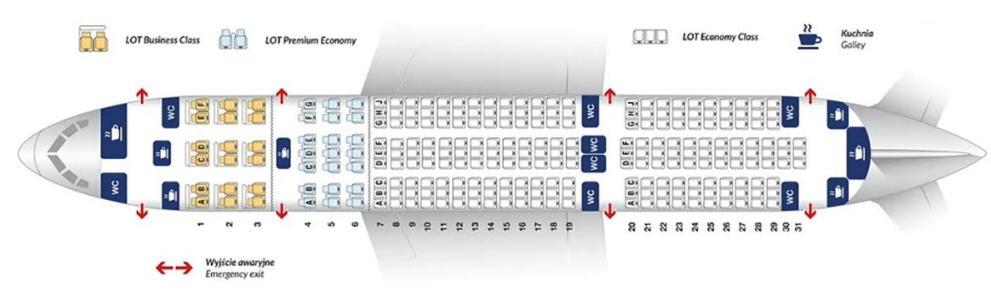

Figure 1. Passenger cabin layout of Boeing 787 Dreamliner

Rycina 1. Aranżacja przestrzeni kabiny pasażerskiej samolotu Boeing 787 Dreamliner

Source: https://www.lot.com/pl/pl/dreamliner-787 [24].

Źródło: https://www.lot.com/pl/pl/dreamliner-787 [24].

The model of the aircraft which provided the geometric framework for simulating the evacuation of air passengers could be made with using three possible techniques:

- a graphical interface with tools for drawing the geometry based on the given object dimensions;

- a graphic interface with an added background image, which is a $2 \mathrm{D}$ graphic file based on which we add geometric elements in places and dimensions as suggested by the background image;

- a graphic interface with imported 2D or 3D graphics, from which we select the elements of geometry necessary to make the model [25].

When starting the construction of a model, the second option presented above was used by introducing the image presented in Figure 1. as a background and using appropriate scaling (using the known length of the passenger cabin). The effects of modelling are illustrated in Figure 2. The cabin model takes into account the geometry of passenger seats, corridor width,
Model samolotu, który stanowił ramy geometryczne do przeprowadzenia symulacji ewakuacji pasażerów samolotu, mógł zostać wykonany przy wykorzystaniu trzech możliwych technik:

- interfejsu graficznego wraz z narzędziami do rysowania geometrii w oparciu o podane wymiary obiektu;

- interfejsu graficznego z dodanym obrazem tła (plik graficzny 2D), na bazie którego dodajemy elementy geometrii w miejscach oraz wymiarach takich, jakie podpowiada nam obraz tła;

- interfejsu graficznego z zaimportowaną grafiką 2D lub 3D, z której wybieramy elementy geometrii niezbędnej do prawidłowego wykonania modelu [25].

Przystępując do budowy modelu, wykorzystano drugą z przedstawionych powyżej opcji, wprowadzając obraz widoczny na rycinie 1 jako tło oraz stosując odpowiednie skalowanie (wykorzystano przy tym znaną długość kabiny pasażerskiej). Efekty modelowania zostały zobrazowane na rycinie 2 . W modelu kabiny uwzględniono geometrię siedzeń pasażerskich, szerokość 
catering facilities, toilets and eight emergency exits (marked 1R, $1 \mathrm{~L}, 2 \mathrm{R}, 2 \mathrm{~L}, 3 \mathrm{R}, 3 \mathrm{~L}, 4 \mathrm{R}, 4 \mathrm{~L}$ ).

Then, the placing of passenger models in the seats was started, assuming that they are in a standing position (due to the limitations of the software application on the acceptable avatar position). The distribution of simplified passenger models is shown in Figure 3. korytarzy, obiekty gastronomii, toalety oraz osiem wyjść ewakuacyjnych (oznaczonych kolejno: 1R, 1L, 2R, 2L, 3R, 3L, 4R, 4L).

Następnie przystąpiono do umieszczenia w miejscach foteli pasażerskich modeli pasażerów, zakładając, iż znajdują się oni w pozycji stojącej (ze względu na ograniczenia programu w zakresie możliwej do przyjęcia pozycji awatara). Rozmieszczenie uproszczonych modeli pasażerów zostało pokazane na rycinie 3.

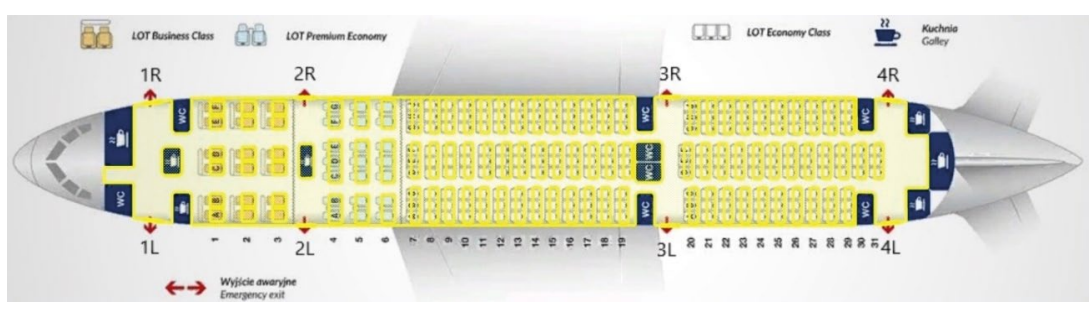

Figure 2. The model of a board of a selected passenger aircraft, made in Pathfinder Rycina 2. Model pokładu wybranego samolotu pasażerskiego wykonany w Pathfinder Source: The in-house elaboration with usage of [24].

Źródło: Opracowanie własne z wykorzystaniem https://www.lot.com/pl/pl/dreamliner-787 [24].

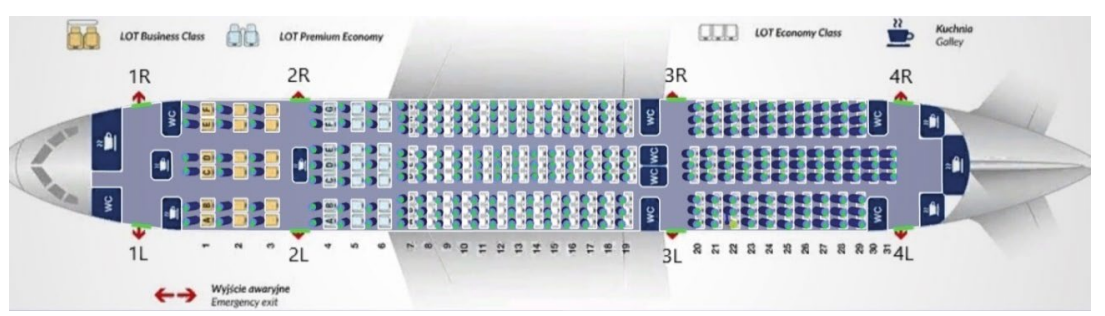

Figure 3. Arrangement of the models for 252 passengers in the passenger compartment, made in the Pathfinder software application Rycina 3. Rozmieszczenie modeli 252 pasażerów w przestrzeni przedziału pasażerskiego wykonane w programie Pathfinder

Source: The in-house elaboration with usage of [24]

Źródło: Opracowanie własne z wykorzystaniem https://www.lot.com/pl/pl/dreamliner-787 [24].

In the next step, a detailed description of the individual models of passengers was started by assigning a profile and behaviour to the models. A small differentiation of passengers in terms of sizes of their bodies has been adopted here, assuming that the majority of passengers will be adults of male dimensions. This is a more unfavourable situation from the point of view of efficient evacuation, because the larger the size of people, the more likely it is that there will be a collision with elements of the passenger compartment or with other people. Therefore, it was assumed that out of 252 passengers on board there are 243 people with shoulder width of $45.58 \mathrm{~cm}$ (this is the diameter of the cylinder surrounding the person's figure) and height of $1.83 \mathrm{~m}$ and 9 people with shoulder width of $40 \mathrm{~cm}$ and height of $1.60 \mathrm{~m}$. In addition, the programme assumes the possibility of momentary reduction of the diameter of the cylinder representing a person to 0.7 of its nominal value in case of congestion (it is a situation, in which a person moves "sideways" for a moment, squeezing his or her arms in the direction of movement). A collision response time of $1.5 \mathrm{~s}$ (standard value in the Pathfinder software application) was
W kolejnym kroku przystąpiono do szczegółowego opisu poszczególnych modeli pasażerów poprzez przypisanie im profilu oraz zachowania. Przyjęto w tym miejscu niewielkie zróżnicowanie pasażerów w zakresie ich wymiarów gabarytowych, zakładając, że większość pasażerów będą stanowić osoby o wymiarach dorosłego mężczyzny. Jest to sytuacja bardziej niekorzystna z punku widzenia sprawnej ewakuacji - im większe wymiary gabarytowe osób, tym większe prawdopodobieństwo wystąpienia kolizji z elementami przedziału pasażerskiego lub innymi osobami. Stąd też przyjęto, iż z pośród 252 pasażerów na pokładzie znajdują się 243 osoby o szerokości ramion $45,58 \mathrm{~cm}$ (jest to średnica walca okalającego sylwetkę osoby) i wysokości 1,83 m oraz 9 osób o szerokości ramion $40 \mathrm{~cm}$ i wysokości 1,60 m. Dodatkowo przyjęto w programie możliwość chwilowego zmniejszenia średnicy walca reprezentującego osobę do 0,7 jej wartości nominalnej w przypadku wystąpienia zatoru (jest to sytuacja, w której osoba porusza się przez chwilę „bokiem”, przeciskając się ramionami w kierunku ruchu). Założono również czas reakcji na kolizję równy 1,5 s (standardowo przyjęta wartość w programie 
also adopted. Another important parameter that defines the passenger profile is the speed of the passenger movement. According to the literature on the subject, with undisturbed pedestrian traffic on horizontal escape routes, the average speed of movement below $1.4 \mathrm{~m} / \mathrm{s}$, usually $1.2 \mathrm{~m} / \mathrm{s}$ [20-22], is usually assumed. Other speed values were also indicated in the literature, for example $1.25 \mathrm{~m} / \mathrm{s}$ according to Paul (in office buildings), $1.19 \mathrm{~m} / \mathrm{s}$ according to Nelson and Mowrer, $1.7 \mathrm{~m} / \mathrm{s}$ for men and $0.8 \mathrm{~m} / \mathrm{s}$ for women according to Thompson and Marchanto $[18,19]$. In this simulation model it was decided to adopt the standard passenger, for Pathfinder, speed of $1.19 \mathrm{~m} / \mathrm{s}$ (according to Nelson and Mowrer). It could have been expected that, in the relatively tight passages of the passenger compartment, this speed would be difficult to achieve due to collisions and congestions.

In the first calculation variant, the behaviours of individual passengers is further defined, assuming that they will be dictated by instructions from the on-board personnel to direct passengers to individual evacuation exits. Therefore, it was assumed that passengers in the "Business Class" compartment will evacuate through two front exits $1 \mathrm{R}$ and $1 \mathrm{~L}$ (18 persons), passengers in the Premium Economy compartment (rows 4-6) and six rows of Economy Class, i.e. from 7 to 12 rows ( 75 persons) will evacuate through $2 \mathrm{R}$ and $2 \mathrm{~L}$ exits. Then Economy Class passengers from rows 13 to 19 and 20 to 21 will evacuate via exits $3 R$ and $3 L$ (81 persons) and Economy Class passengers from rows 22 to 31 will evacuate via exits $4 R$ and $4 L$ (78 persons). When assigning passengers to the individual emergency exits, an attempt was made to divide exits $2 R, 2 \mathrm{~L}, 3 \mathrm{R}, 3 \mathrm{~L}$ and $4 \mathrm{R}, 4 \mathrm{~L}$ as evenly as possible, which has led to the following division: exits $2 R$ and $2 L$ -75 persons, exits $3 R$ and $3 L-81$ persons, exits $4 R$ and $4 L$ - 78 persons. When assigning people into individual entrances, it was stated that the $1 \mathrm{R}$ and $1 \mathrm{~L}$ entrances will only be used by passengers in the Business Class, as it cannot be assumed that passengers in the Premium Economy compartment will bypass the closest $2 R$ and $2 L$ exits and head for $1 R$ and $1 L$ exits. The first calculation variant was treated as a preliminary check of the possibility to evacuate passengers in the proposed division into individual evacuation exits and did not include the evacuation of on-board personnel. A view of a model of an aircraft with passengers, which such aircraft is prepared for evacuation simulation, is shown in Figure 4.
Pathfinder). Kolejnym ważnym parametrem, który definiuje profil pasażera, jest prędkość jego poruszania się. Według literatury przedmiotu, przy niezakłóconym ruchu pieszych po poziomych drogach ewakuacyjnych, zwykle przyjmuje się średnią prędkość przemieszczania poniżej 1,4 m/s (najczęściej jest to 1,2 m/s) [20-22]. W literaturze zostały wskazane także inne wartości prędkości, np.: $1,25 \mathrm{~m} / \mathrm{s}$ według Paulsa (w budynkach biurowych), 1,19 m/s według Nelsona i Mowrera, 1,7 m/s dla mężczyzn i 0,8 m/s dla kobiet według Thompsona i Marchanta [18-19]. W niniejszym modelu symulacyjnym postanowiono przyjąć standardową dla Pathfindera prędkość poruszania się pasażerów 1,19 m/s (wg Nelsona i Mowrera). Można się było spodziewać, iż w stosunkowo ciasnych przejściach przedziału pasażerskiego prędkość ta będzie trudna do osiągnięcia ze względu na występujące kolizje i zatory.

W pierwszym wariancie obliczeniowym zdefiniowano dodatkowo zachowania poszczególnych pasażerów, zakładając, że będą one podyktowane wskazówkami personelu pokładowego kierującego ich do poszczególnych wyjść ewakuacyjnych. Stąd też przyjęto, iż pasażerowie przedziału Business Class będą się ewakuowali przez dwa przednie wyjścia 1R i 1L (18 osób), pasażerowie przedziału Premium Economy (rzędy 4-6) oraz sześć rzędów Economy Class tj. od 7 do 12 rzędu (75 osób), będą się ewakuowali przez wyjścia 2R i 2L. Następnie pasażerowie przedziału Economy Class z rzędów od 13 do 19 oraz od 20 do 21 będą się ewakuowali przez wyjścia 3R i 3L (81 osób), zaś pasażerowie przedziału Economy Class z rzędów od 22 do 31 - przez wyjścia 4R i 4L (78 osób). Podczas przydzielania pasażerów do poszczególnych wyjść ewakuacyjnych starano się dokonać możliwie równomiernego podziału pomiędzy wyjścia $2 \mathrm{R}, 2 \mathrm{~L}, 3 \mathrm{R}, 3 \mathrm{~L}$ oraz $4 \mathrm{R}, 4 \mathrm{~L}$, co doprowadziło do następującego przyporządkowania: wyjścia $2 \mathrm{R}$ i $2 \mathrm{~L}-75$ osób, wyjścia $3 \mathrm{R}$ i 3L - 81 osób, wyjścia 4R i 4L - 78 osób. Przy przypisywaniu osób do poszczególnych wejść stwierdzono, iż wejścia 1R i 1L będą wykorzystywane jedynie przez pasażerów przedziału Business Class, ponieważ nie można zakładać, iż pasażerowie przedziału Premium Economy ominą najbliższe sobie wyjścia 2R i 2L i skierują się do wyjść 1R i 1L. Pierwszy wariant obliczeniowy został potraktowany jako wstępne sprawdzenie możliwości ewakuacji pasażerów w zaproponowanym podziale na poszczególne wyjścia ewakuacyjne i nie uwzględniał ewakuacji personelu pokładowego. Widok modelu samolotu z pasażerami przygotowanego do przeprowadzenia symulacji ewakuacji został pokazany na rycinie 4 .

Figure 4. View of the aircraft model with 252 passengers, which such aircraft is prepared for evacuation simulation in the first calculation variant Rycina 4. Widok modelu samolotu z 252 pasażerami przygotowanego do przeprowadzenia symulacji ewakuacji w pierwszym wariancie obliczeniowym Source: The in-house elaboration with usage of [24]. Źródło: Opracowanie własne z wykorzystaniem https://www.lot.com/pl/pl/dreamliner-787 [24].

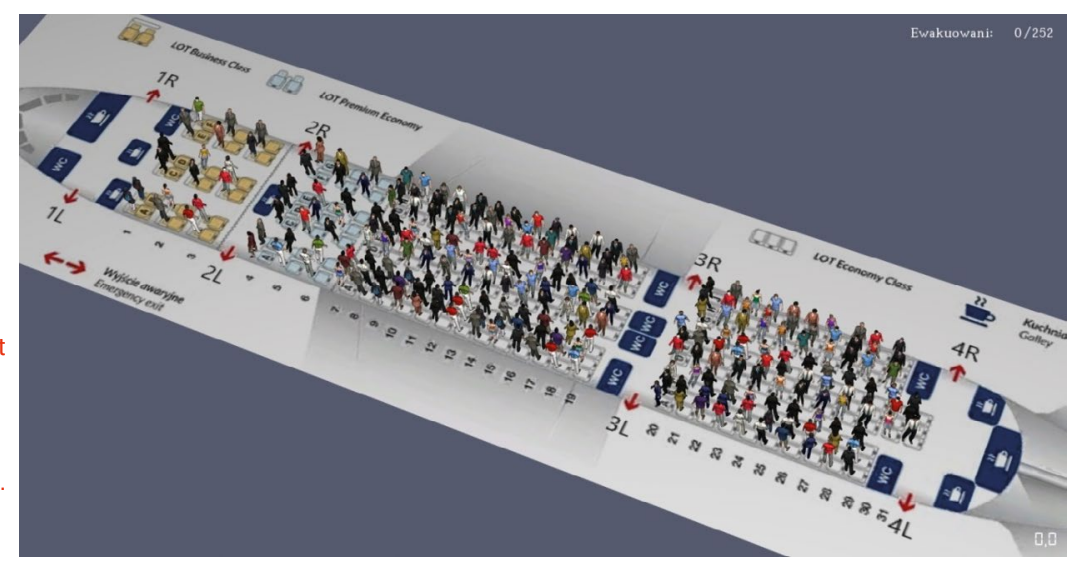


The first simulation option resulted in a total evacuation time of 68 seconds. However, it was found that there is passenger congestion in rows 22 and 23 , which affects the final evacuation time. It was therefore decided to carry out a second variant of the simulation, in which the allocation of passengers to individual emergency exits was uneven. Namely, passengers in the Business Class, Premium Economy and six rows of Economy Class will evacuate as before. The difference in the second option is that Economy Class passengers from rows 13 to 23 will evacuate via exits $3 R$ and $3 \mathrm{~L}$ (99 persons), while Economy Class passengers from rows 24 to 31 will evacuate via exits $4 R$ and $4 \mathrm{~L}$ (60 persons). In the simulation carried out according to the second variant, an evacuation time of 58.5 seconds was obtained, which is 9.5 seconds shorter than the previous one. It can therefore be concluded that shorter evacuation times can be achieved not by distributing the number of passengers evenly over the various emergency exits, but by eliminating potential congestions and collisions between evacuees.

In a further, third simulation option, it was decided to examine the impact of increasing the maximum passenger speed on evacuation times. It was assumed that passengers could move, in the absence of a collisions, at a speed described by a normal distribution with an expected value of $1.3 \mathrm{~m} / \mathrm{s}$, standard deviation of $0.03 \mathrm{~m} / \mathrm{s}$ (in the first and second variant the speed was $1.19 \mathrm{~m} / \mathrm{s}$ ). The simulation resulted in the time period of $61.5 \mathrm{sec}-$ onds, which is worse than in the previous variant. It can therefore be concluded that, in the case of passengers moving in tight corridors of the passenger compartment, paradoxically, the higher maximum speed of passenger movement caused more collisions and therefore had a negative impact on evacuation times.

In the next fourth variant, it was decided to make an attempt to simulate the evacuation for the conditions, in which the certification tests for evacuation from the aircraft are carried out, i.e. for not being able to use half of the evacuation exits. In this simulation variant, the assignment of passengers to individual pairs of doors was used as in the second variant, however, the possibility to use the evacuation doors on the left side of the aircraft was closed (this imitates a situation in which the left outer side of the aircraft is covered by a fire, e.g. spilled aviation fuel). The other parameters of profiles and parameters of passengers' behaviours remained the same as in the second variant of the simulation. As expected, passengers, looking for the shortest way to the exits on the right-hand side of the aircraft, crowded into tight spaces between rows of seats causing a significant increase in evacuation time of 121.5 seconds. In addition, it should be noted that in this option, there was no additional steering of passenger traffic by on-board personnel in terms of using the most effective escape routes. The view of the situation of crowding and congestions, on the right side of the aircraft, in this simulation variant, is shown in Figure 5.
W wyniku przeprowadzenia pierwszego wariantu symulacji wyznaczono całkowity czas ewakuacji wynoszący 68 sekund. Stwierdzono jednak, że występuje zator pasażerów w rzędach 22 i 23, co wpływa na końcowy czas ewakuacji. Postanowiono więc wykonać drugi wariant symulacji, w którym dokonano nierównomiernego przydziału pasażerów do poszczególnych wyjść ewakuacyjnych. Mianowicie, pasażerowie przedziału Business Class, Premium Economy oraz sześć rzędów Economy Class będą się ewakuowali podobnie jak w przypadku wariantu pierwszego. Różnica w drugim wariancie polega tym, iż pasażerowie przedziału Economy Class z rzędów od 13 do 23 będą się ewakuowali przez wyjścia 3R i 3L (99 osób), natomiast pasażerowie przedziału Economy Class z rzędów od 24 do 31 będą się ewakuowali przez wyjścia 4R i 4L (60 osób). W symulacji przeprowadzonej według drugiego wariantu uzyskano czas ewakuacji wynoszący 58,5 sekundy, czyli krótszy od poprzedniego o 9,5 sekundy. Można więc wysnuć wniosek, iż krótszy czas ewakuacji możemy uzyskać nie poprzez równomierny rozkład ilości pasażerów na poszczególne wyjścia ewakuacyjne, lecz likwidując potencjalne zatory i kolizje ewakuowanych osób.

W kolejnym, trzecim wariancie symulacji postanowiono zbadać wpływ zwiększenia maksymalnej prędkości poruszania się pasażerów na czas ewakuacji. Założono, iż pasażerowie mogą poruszać się - przy braku kolizji - z prędkością opisaną rozkładem normalnym o wartości oczekiwanej 1,3 m/s, odchyleniu standardowym $0,03 \mathrm{~m} / \mathrm{s}$ (w pierwszym i drugim wariancie prędkość wynosiła 1,19 m/s). W wyniku przeprowadzonej symulacji uzyskano czas ewakuacji 61,5 sekundy, czyli gorszy niż w poprzednim wariancie. Można więc stwierdzić, iż w przypadku poruszania się pasażerów w ciasnych korytarzach przedziału pasażerskiego, większa prędkość maksymalna poruszania się pasażerów powodowała większą ilość kolizji, a co za tym idzie negatywnie wpłynęła na czas ewakuacji.

W czwartym wariancie podjęto próbę wykonania symulacji ewakuacji dla warunków, w których prowadzone są testy certyfikacyjne ewakuacji z samolotu, tj. dla braku możliwości użycia połowy wyjść ewakuacyjnych. W tym wariancie symulacji wykorzystano przydział pasażerów do poszczególnych par drzwi jak w wariancie drugim, jednakże zablokowano możliwość korzystania z drzwi ewakuacyjnych z lewej strony samolotu (imituje to sytuację, w której lewa zewnętrzna strona samolotu objęta jest pożarem, np. rozlanego paliwa lotniczego). Pozostałe parametry profili oraz zachowań pasażerów pozostały takie same jak w wariancie drugim. Jak można było się spodziewać, pasażerowie - poszukując najkrótszej drogi do wyjść znajdujących się po prawej stronie samolotu - stłoczyli się w ciasnych przestrzeniach pomiędzy rzędami siedzeń, co znaczne wydłużyło czas ewakuacji, który wyniósł 121,5 sekundy. Dodatkowo należy zaznaczyć, iż $w$ tym wariancie brak było dodatkowego kierowania ruchem pasażerów przez personel pokładowy w zakresie wykorzystania najbardziej efektywnych dróg ewakuacji. Widok sytuacji powstania tłoku i zatorów, po prawej stronie samolotu, w tym wariancie symulacji obrazuje rycina 5 . 


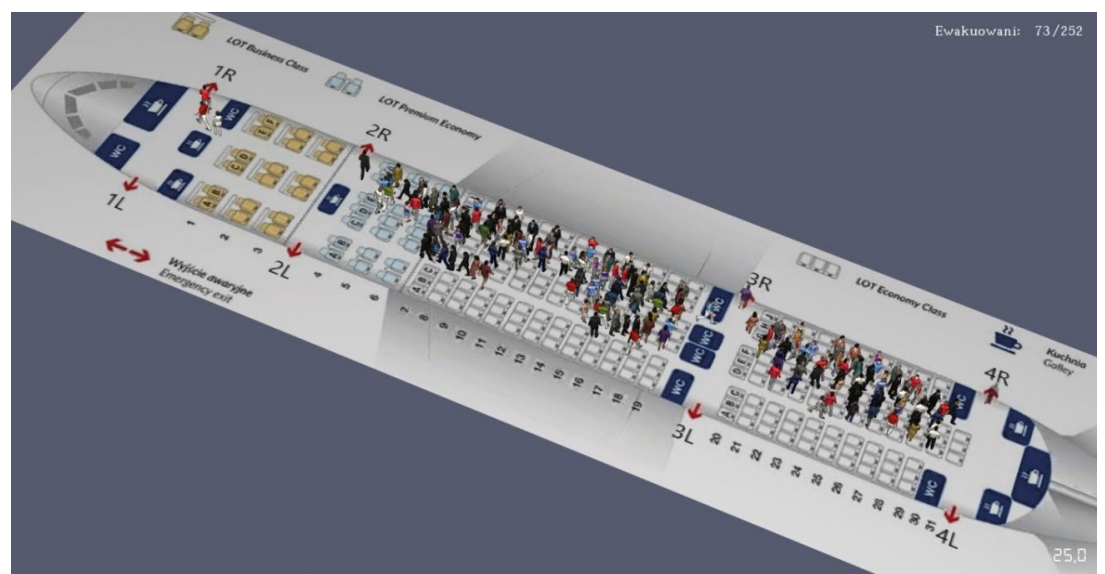

Figure 5. View of congestions in the fourth simulation variant (available door: 1R-4R) Rycina 5. Widok zatorów w czwartym wariancie symulacji (dostępne drzwi: 1R-4R)

Source: The in-house elaboration with usage of [24].

Źródło: Opracowanie własne z wykorzystaniem https://www.lot.com/pl/pl/dreamliner-787 [24]

It was therefore decided to carry out a simulation in the fifth variant, in which one member of on-board personnel was deployed at each emergency exit (according to their actual deployment during take-off and landing). It has been assumed that the on-board personnel directs the movement of passengers by instructing them to move first through corridors on both sides of the fuselage near the evacuation exits and only then directs them to the evacuation exits on the right side of the aircraft (the evacuation exits on the left side are still closed in this variant simulating a fire on the left side of the aircraft). In addition, it has been assumed that after evacuation of people from a particular compartment of the passenger cabin, the on-board personnel must walk along that compartment to check between rows of seats to see if all passengers have left their seats (this is a requirement of the evacuation procedure). In the simulation model, the traffic of passengers and on-board personnel was executed by adding to their behaviours the need to pass through specific places on board the aircraft (so-called waypoints) and only afterwards heading to an evacuation exit. The visualisation of the deployment of on-board personnel, passengers and "road points" is presented in Figure 6. Red circles with a larger diameter are waypoints for passengers, while red circles with smaller diameters are waypoints for on-board personnel.
Piąty wariant symulacji zakładał rozmieszczenie po jednym członku załogi pokładowej przy każdym wyjściu (zgodnie z ich faktycznym rozmieszczeniem podczas startu i lądowania). Założono, iż personel pokładowy najpierw zarządza ruchem pasażerów, nakazując, aby przemieszczali się oni korytarzami po obu stronach kadłuba w pobliżu wyjść ewakuacyjnych, a dopiero później kieruje ich do wyjść ewakuacyjnych po prawej stronie samolotu (wyjścia ewakuacyjne po lewej stronie są w tym wariancie nadal zamknięte z powodu pożaru po lewej stronie samolotu). Dodatkowo przyjęto, iż po ewakuacji ludzi z określonego przedziału kabiny pasażerskiej członkowie załogi pokładowej muszą przejść wzdłuż tego przedziału, aby sprawdzić pomiędzy rzędami siedzeń, czy wszyscy pasażerowie opuścili swoje miejsca (jest to wymóg procedury ewakuacyjnej). W modelu symulacyjnym kierowanie ruchem pasażerów i personelu pokładowego było realizowane poprzez dodanie do ich zachowań konieczności przejścia przez określone miejsca na pokładzie samolotu (tzw. punkty drogi), a dopiero później skierowanie ich do wyjścia ewakuacyjnego. Wizualizacja rozmieszczenia personelu pokładowego, pasażerów oraz punków drogi została przedstawiona na rycinie 6. Czerwone okręgi o większej średnicy to punkty drogi pasażerów, natomiast czerwone okręgi o mniejszych średnicach to punkty drogi personelu pokładowego.

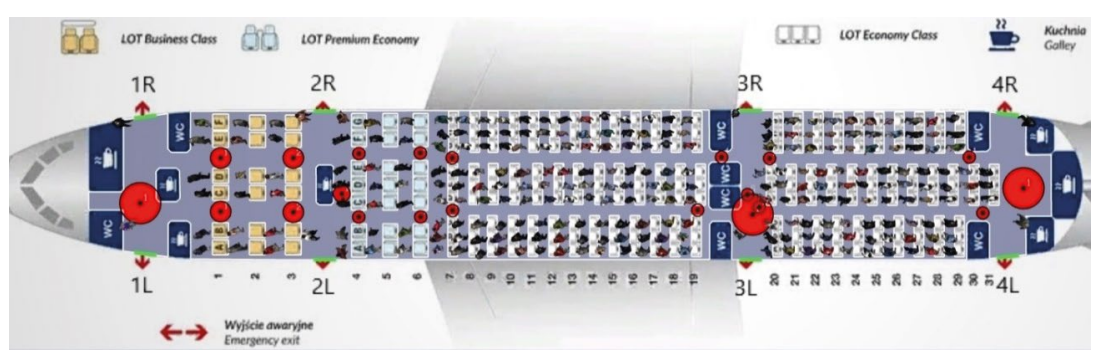

Figure 6. Deployment of on-board personnel, passengers and "way-points" in the fifth simulation variant Rycina 6. Rozmieszczenie personelu pokładowego, pasażerów oraz punków drogi w piątym wariancie symulacji

Source: The in-house elaboration with usage of [24].

Źródło: Opracowanie własne z wykorzystaniem https://www.lot.com/pl/pl/dreamliner-787 [24] 
As a result of the evacuation simulation, a satisfactory time of 88.5 seconds was obtained for the assumptions of the fifth evacuation variant, (which is within the maximum time of $90 \mathrm{sec}-$ onds, required by the regulations for evacuation by half of all evacuation exits). It should also be noted that after adding members of on-board personnel, the number of people evacuated has increased to 260 . The visualisation of a more even distribution of evacuating passengers, compared to the previous variant, is shown in Figure 7.
W wyniku przeprowadzenia symulacji ewakuacji dla tak przyjętych założeń wariantu piątego uzyskano zadowalający czas 88,5 sekundy (czas ten mieści się w wymaganym przez przepisy maksymalnym czasie 90 sekund dla ewakuacji prowadzonej w warunkach połowy dostępnych wyjść ewakuacyjnych). Należy również zaznaczyć, iż po dodaniu członków personelu pokładowego liczba osób ewakuowanych wzrosła do 260 . Wizualizacja bardziej równomiernego - w porównaniu do poprzedniego wariantu - rozmieszczenia ewakuujących się pasażerów, została przedstawiona na rycinie 7 .

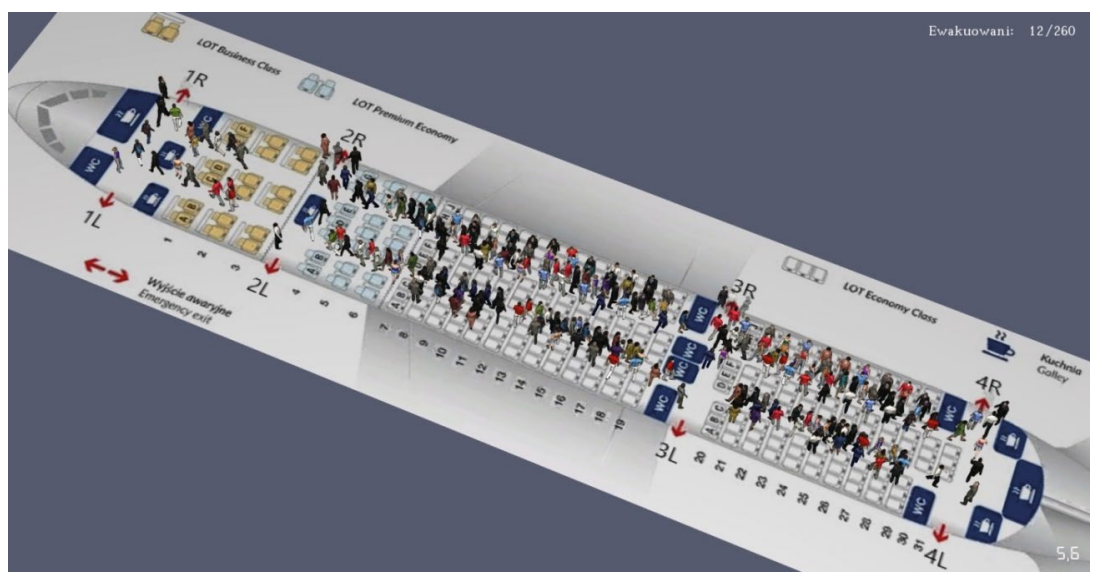

Figure 7. The visualisation of the even distribution of evacuating passengers for the fifth simulation variant (252 passengers and 8 on-board personnel members)

Rycina 7. Wizualizacja równomiernego rozmieszczenia ewakuujących się pasażerów dla piątego wariantu symulacji (252 pasażerów i 8 członków personelu pokładowego)

Source: The in-house elaboration with usage of [24].

Źródło: Opracowanie własne z wykorzystaniem https://www.lot.com/pl/pl/dreamliner-787 [24].

The last sixth variant of the simulation model attempts to reduce the evacuation time as much as possible on the basis of detailed observation of the behaviours of the on-board personnel in the final evacuation stage. Correction of the personnel's behaviour was made so that they leave the aircraft faster, thanks to which the evacuation time of 85.8 seconds was obtained (for certification conditions of passenger aircraft in terms of evacuation requirements, i.e. half of the evacuation exits available).

As it has already been mentioned, the Pathfider software application allows to obtain, apart from the evacuation time, a number of useful resultant values, such as, for example, the distribution of the flow of passengers per second through available evacuation exits, presented in Figure 8, or the distribution of the change in time of the number of passengers in the aircraft cabin during the evacuation in the sixth variant of the simulation, presented in Figure 9.
W ostatnim, szóstym wariancie modelu symulacyjnego podjęto próbę maksymalnego skrócenia czasu ewakuacji na podstawie szczegółowej obserwacji zachowania się personelu pokładowego w ostatnim etapie ewakuacji. Dokonano korekty zachowań personelu, tak aby szybciej opuścili samolot. Dzięki temu uzyskano czas ewakuacji wynoszący 85,8 sekundy (dla warunków certyfikacji samolotu pasażerskiego w aspekcie wymagań ewakuacji, tj. dostępna połowa wyjść ewakuacyjnych).

Jak już zostało to wspomniane, oprogramowanie Pathfider poza czasem ewakuacji pozwala uzyskać, szereg przydatnych wielkości wynikowych, jak np. przedstawiony na rycinie 8 rozkład przepływu pasażerów w ciągu sekundy przez dostępne wyjścia ewakuacyjne, czy też zaprezentowany na rycinie 9 rozkład zmiany w czasie liczby pasażerów w kabinie samolotu w trakcie ewakuacji w szóstym wariancie symulacji. 


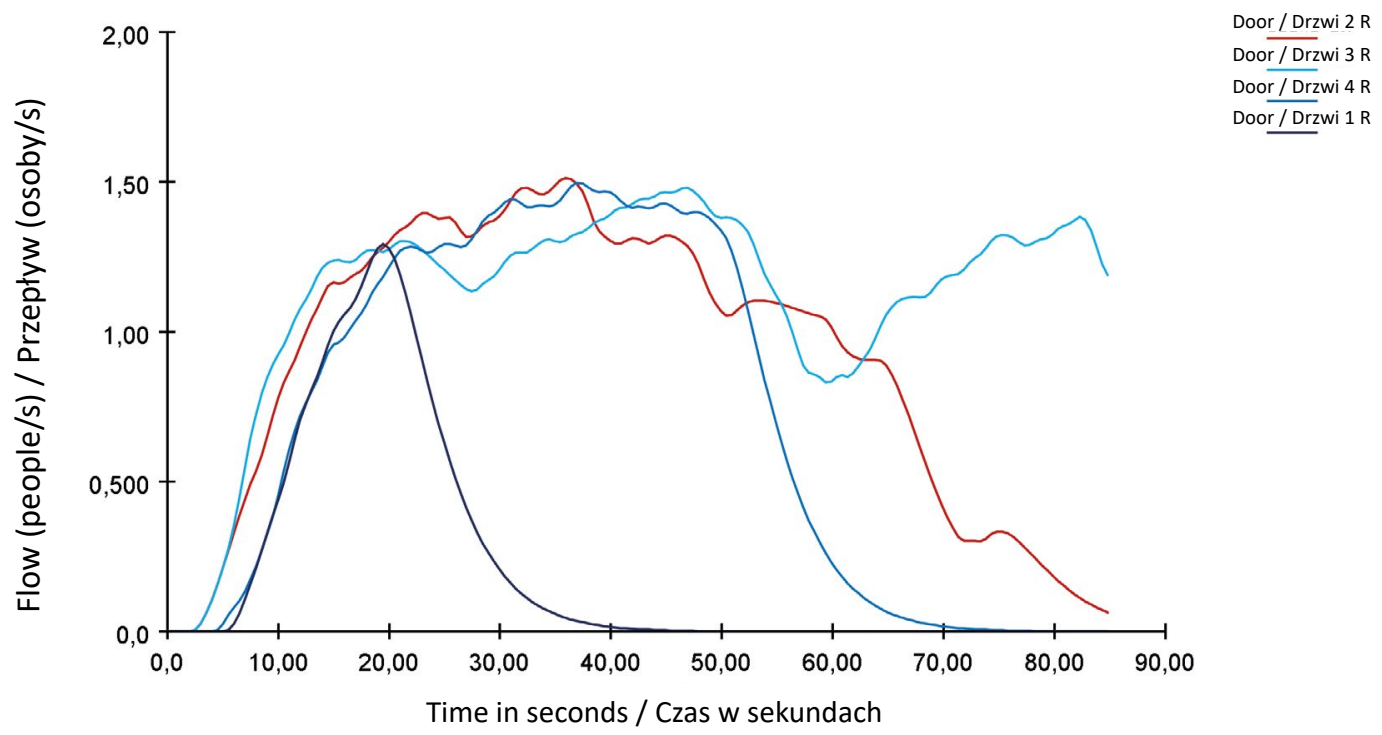

Figure 8. The distribution of passenger flows through available evacuation exits in the sixth variant of the simulation (in seconds) Rycina 8. Rozkład przepływu pasażerów przez dostępne wyjścia ewakuacyjne w szóstym wariancie symulacji (w sekundach)

Source: Own elaboration.

Źródło: Opracowanie własne.

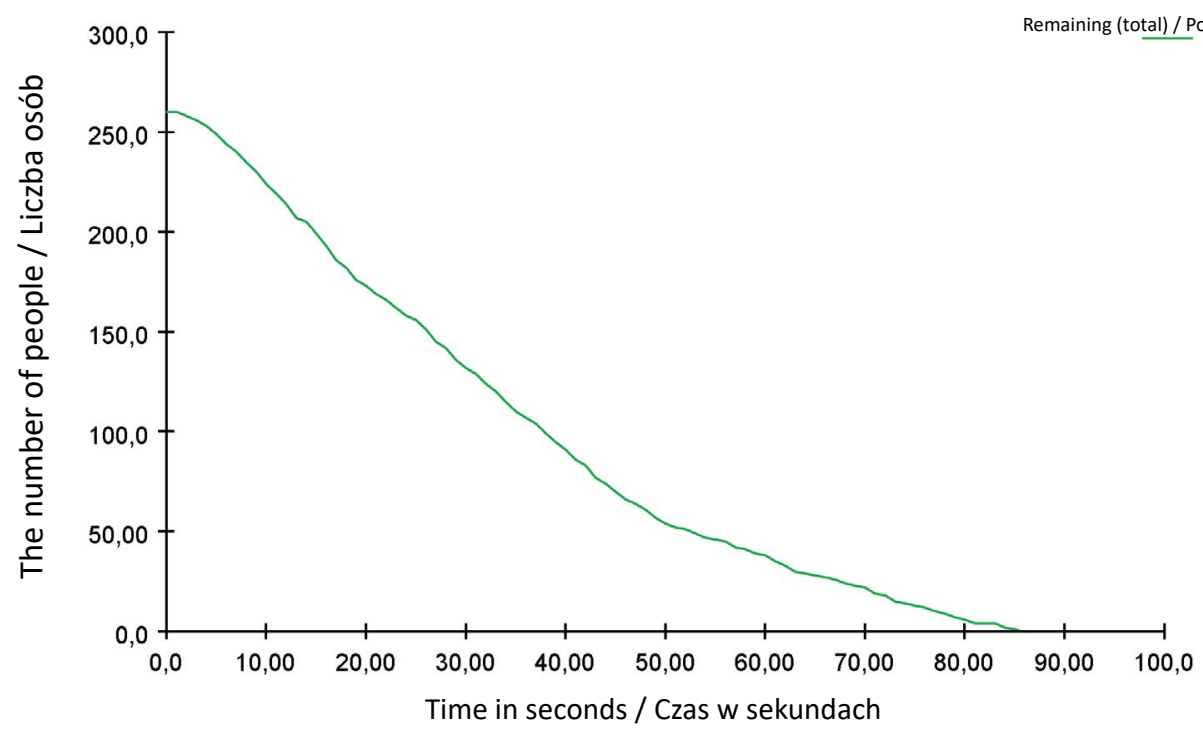

Figure 9. Timetable of change in time of the number of passengers in the passenger compartment of the aircraft during an evacuation in the sixth simulation variant

Rycina 9. Rozkład zmiany w czasie liczby pasażerów w kabinie samolotu w trakcie ewakuacji w szóstym wariancie symulacji

Source: Own elaboration.

Źródło: Opracowanie własne.

The use of the Pathfinder software application makes it possible to search for optimal solutions in terms of evacuation time, by analysing films presenting the visualisation of the evacuation process together with additional information on the parameters
Wykorzystanie oprogramowania Pathfinder ułatwia poszukiwanie optymalnych rozwiązań pod kątem czasu ewakuacji, a także analizę filmów przedstawiających wizualizację procesu ewakuacji wraz z wyświetlaniem dodatkowych informacji 
of people's movement. The examples of selected shots, from films presenting simulation results, are showing:

- illustration of the number of passengers per square metre (density) at the selected moment of evacuation - Figure 10;

- illustration of passengers' speed of movement at the selected moment of evacuation - Figure 11;

- illustration of the number of passengers queuing at the selected moment of evacuation - Figure 12. dotyczących parametrów przemieszczania się osób. Przykłady wybranych kadrów z filmów prezentują wyniki symulacji poprzez zobrazowanie:

- liczby pasażerów przypadających na metr kwadratowy (gęstość) w wybranym momencie ewakuacji - rycina 10;

- prędkości poruszania się pasażerów w wybranym momencie ewakuacji - rycina 11;

- liczby pasażerów oczekujących w kolejce w wybranym momencie ewakuacji - rycina 12.

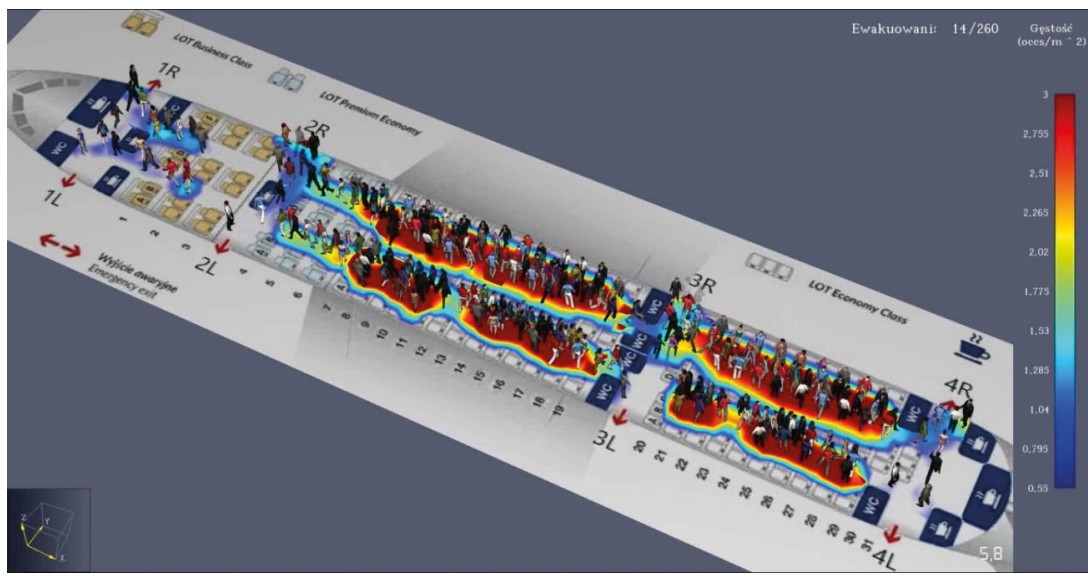

Figure 10. Illustration of the number of passengers per square metre during an evacuation for the sixth simulation variant Rycina 10. Zobrazowanie liczby pasażerów przypadającej na metr kwadratowy w trakcie ewakuacji dla szóstego wariantu symulacji Source: Own elaboration with usage of [24]

Źródło: Opracowanie własne z wykorzystaniem https://www.lot.com/pl/pl/dreamliner-787 [24].

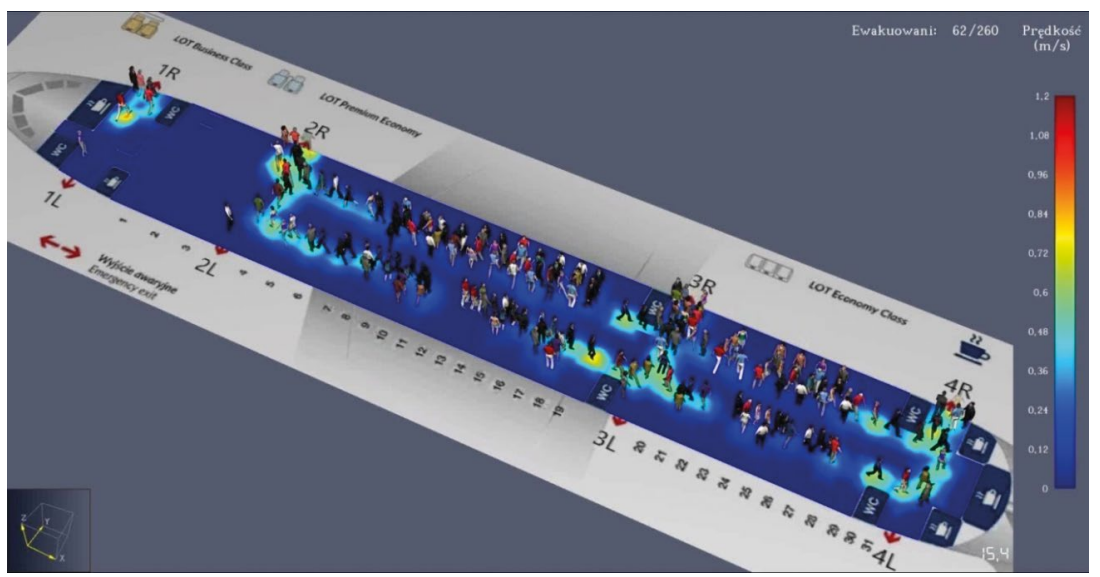

Figure 11. Illustration of passengers' speed of movement at the selected moment of evacuation for the sixth simulation variant Rycina 11. Zobrazowanie prędkości poruszania się pasażerów w wybranym momencie ewakuacji dla szóstego wariantu symulacji Source: Own elaboration with usage of [24].

Źródło: Opracowanie własne z wykorzystaniem https://www.lot.com/pl/pl/dreamliner-787 [24]. 


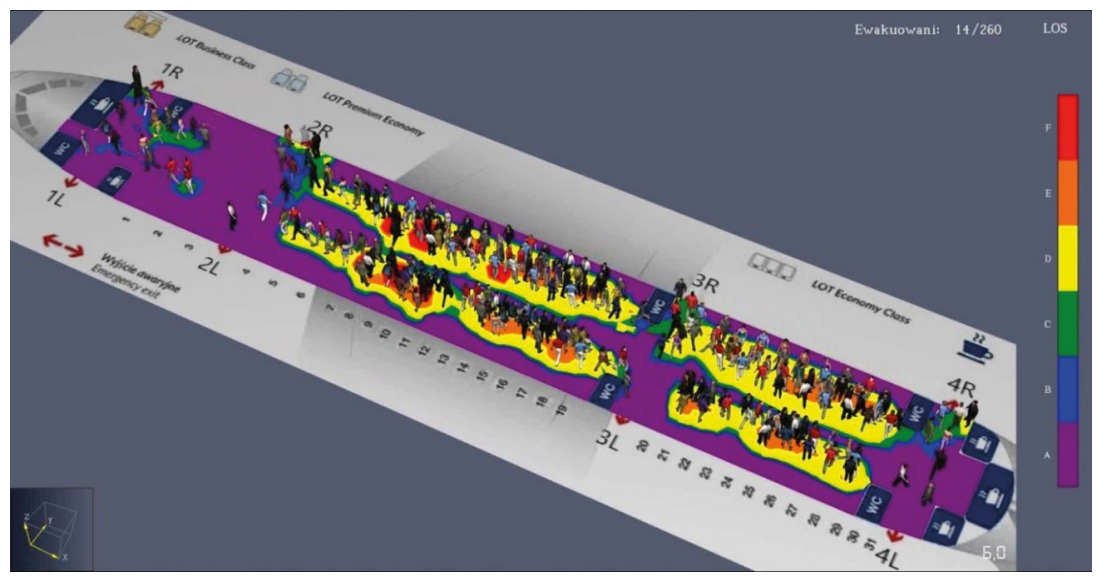

Figure 12. Illustration of the number of passengers queuing at the selected time of evacuation for the sixth simulation option Rycina 12. Zobrazowanie liczby pasażerów oczekujących w kolejce w wybranym momencie ewakuacji dla szóstego wariantu symulacji Source: Own elaboration with usage of [24].

Źródło: Opracowanie własne z wykorzystaniem https://www.lot.com/pl/pl/dreamliner-787 [24]

The simulation models presented in this paper and the results obtained as well as the possibilities of three-dimensional visualization of the research results, presented above, allow to draw many interesting conclusions and prove the possibility of using the Pathfinder software application to investigate the process of evacuation from passenger aircrafts.

\section{Summary}

On the basis of the analysis of the problem presented in the study, it can be concluded that the highest possible survival rate for passengers and crew in air accidents is due to constantly improved regulations in the area of airworthiness, operational requirements, improvement of aircraft design in the area of emergency evacuation systems and their technical reliability, as well as in the area of constantly improved procedures and training for flight crew and on-board personnel.

The evacuation simulations carried out and the results obtained provide an opportunity to get a number of conclusions. Namely, the proper efficiency of the evacuation process was achieved after the implementation of a change in the mathematically calculated even distributing the quantities of passengers to individual emergency exits, which made it possible to direct them in such a way as to avoid congestions in sensitive areas of the passenger cabin. Also, the increase in passengers' maximum speed has not led to a reduction in evacuation times; on the contrary, it has increased the number of collisions arising and increased the time needed to leave the aircraft. Analysing the results of the fifth simulation variant, it can be said that one of the key issues affecting the efficiency of an evacuation is the proper organisation of the evacuation by the on-board personnel, who, by guiding the passengers through the proper escape routes (geometrically most advantageous gangways), leads to the most efficient execution. It should also be added that the simulations
Przedstawione w niniejszym artykule modele symulacyjne oraz uzyskane rezultaty, jak również zamieszczone powyżej trójwymiarowe wizualizacje wyników badań, pozwalają na wyciągnięcie wielu cennych wniosków. Tym samym dowodzą przydatności oprogramowania Pathfinder podczas badania procesu ewakuacji z samolotów pasażerskich.

\section{Podsumowanie}

Na podstawie przedstawionej w niniejszej pracy analizy problemu można stwierdzić, iż obecna wysokość przeżywalności pasażerów oraz załogi w wypadkach lotniczych jest zasługą ciągle udoskonalanych regulacji dotyczących zdatności do lotu, wymagań operacyjnych, ulepszania konstrukcji statków powietrznych w zakresie systemów awaryjnej ewakuacji oraz ich niezawodności technicznej, a także nieustannie aktualizowanych procedur i szkoleń załogi lotniczej i pokładowej.

Przeprowadzone symulacje ewakuacji oraz uzyskane rezultaty prowadzą do szeregu wniosków. Mianowicie, właściwa efektywność przebiegu ewakuacji została osiągnięta po wprowadzeniu zmiany wyliczonego matematycznie równomiernego podziału liczby pasażerów do poszczególnych wyjść ewakuacyjnych, na takie ich pokierowanie, które pozwoliło uniknąć powstawania zatorów w newralgicznych miejscach kabiny pasażerskiej. Zwiększenie maksymalnej prędkości poruszania się pasażerów nie doprowadziło do skrócenia czasu ewakuacji, wprost przeciwnie - zwiększyło liczbę powstających kolizji i wydłużyło czas potrzebny do opuszczenia samolotu. Analizując wyniki piątego wariantu symulacji, można stwierdzić, iż jedną z kluczowych kwestii wpływających na sprawność ewakuacji jest prawidłowa jej organizacja przez personel pokładowy, który kierując pasażerów przez właściwe drogi ewakuacji (najkorzystniejsze geometrycznie przejścia) czyni cały proces bardziej efektywnym. Należy dodać, że przeprowadzone symulacje w wariantach 
carried out in the fifth and sixth variants allowed to obtain satisfactory evacuation times, which are within the required 90 seconds of the maximum time needed for an aircraft emergency abandonment (as required by the certification of the passenger aircraft in terms of evacuation). Of course, the positive result of the simulation was also due to the use of the cabin geometry of the existing aircraft, which meets all passenger safety requirements. Unfortunately, the lack of publicly available information on the actual time of evacuation obtained in the certification tests, for the passenger compartment arrangement analysed in the paper, made it impossible to make a direct quantitative comparison between the results of simulation and experimental tests.

It is worth stressing that already in the process of designing the interior of an aircraft cabin, one should remember to prepare it for certification tests in terms of evacuation. The proper arrangement of passenger space must take into account the preservation of the appropriate width of corridors and passageways, which largely determines the time of evacuation.

The simulation models presented in this paper and the results obtained in six different variants as well as the presented wide possibilities of three-dimensional visualization of the research results allow to draw many interesting conclusions and give a rational basis for using the Pathfinder software to investigate the process of evacuation from passenger aircraft. Such simulation programmes can be used in the aircraft design process, in preparing the aircrafts for testing, in forming evacuation procedures, in training on-board personnel and in investigating air accidents.

\section{Literature / Literatura}

[1] Krasnowska V., Sałustowicz N., Najbardziej niesamowite katastrofy lotnicze, Bellona, Warszawa 2006.

[2] http://www.aviation-safety.net/ [dostęp: 22.09.2020].

[3] Klich E., Bezpieczeństwo lotów w transporcie lotniczym, Naukowy Instytut Technologii Eksploatacji, 2012.

[4] Galea E., Owen M., Lawrence P., Filippidis L., The airEXODUS Evacuation Model and its Application to Evacuation Certification, Crew Training and Accident Investigation, w: Proceedings of the Aircraft Cabin Safety Conference, 20-21 March 1997, Royal Aeronautical Society, 15.1-15.14.

[5] Gwynne S., Galea E., Owen M., Lawrence P., Filippidis L., A Review of the Methodologies Used in Evacuation Modelling, "Fire and Materials" 1999, 23, 6, 383-389, https://doi. org/10.1002/(SICI)1099-1018(199911/12)23:6<383::AID-FAM715>3.0.CO;2-2.

[6] Galea E., Owen M., Lawrence P., Filippidis L., The Numerical Simulation of Aircraft Evacuation and its Application to Aircraft Design and Certification, "The Aeronautical Journal" 1998, 301-312.

[7] Galea E., Owen M., Lawrence P., Filippidis L., The Numerical Simulation of Aircraft Evacuation and its Application to Aircraft Safety, w: Proc Human Behaviour in Fire, J. Shields (red.), 1998, 529-540 piątym i szóstym pozwoliły uzyskać zadowalające czasy ewakuacji, które mieszczą się w wymaganych 90 sekundach maksymalnego czasu potrzebnego na awaryjne opuszczenie samolotu (wg wymagań certyfikacji samolotu pasażerskiego w aspekcie ewakuacji). Oczywiście uzyskanie pozytywnego wyniku symulacji było również efektem wykorzystania geometrii kabiny pasażerskiej istniejącego samolotu, który spełnia wszystkie wymagania w zakresie bezpieczeństwa pasażerów. Niestety brak publicznie dostępnej informacji na temat rzeczywistego czasu ewakuacji uzyskanego w testach certyfikacyjnych dla analizowanej w pracy aranżacji kabiny pasażerskiej uniemożliwił bezpośrednie porównanie ilościowe wyników badań symulacyjnych i eksperymentalnych.

Warto podkreślić, że już w procesie projektowania wnętrza kabiny samolotu należy pamiętać o przygotowaniu jej do badań certyfikacyjnych pod względem ewakuacji. Właściwa aranżacja przestrzeni pasażerskiej musi uwzględniać odpowiednią szerokość korytarzy i przejść, co w znacznej mierze determinuje czas ewakuacji.

Przedstawione $w$ niniejszym artykule modele symulacyjne i uzyskane rezultaty w sześciu różnych wariantach oraz zaprezentowane szerokie możliwości w zakresie trójwymiarowych wizualizacji wyników badań pozwalają na wyciągnięcie wielu ciekawych wniosków i dają racjonalne podstawy do wykorzystania oprogramowania Pathfinder do badania procesu ewakuacji z samolotów pasażerskich. Tego typu programy symulacyjne mogą być wykorzystywane w procesie projektowania samolotów, przygotowywania ich do badań testowych, kształtowania procedur ewakuacyjnych, szkoleń personelu pokładowego oraz badania wypadków lotniczych.

[8] Burian B. K., Jameson S., Sindall T., Terry P. D. J., Whittingham D. L., Emergency Evacuation of Commercial Passenger Aeroplanes, Royal Aeronautical Society, London 2018.

[9] Butcher N. J., Barnett J. C, Buckland T., Emergency Evacuation of Commercial Passenger Aeroplanes, Second edition 2020, Royal Aeronautical Society, London 2020.

[10] https://www.aerosociety.com/news/emergency-evacuation-time-for-a-rethink/ [dostęp: 22.09.2020].

[11] Grant R. L., Muir H. C., Design Considerations for Enhanced Passenger Aircraft Evacuation, w: Encyclopaedia of Aerospace Engineering, Volume 8, R. Blockley, W. Shyy (red.), John Wiley and Sons Ltd., West Sussex 2010, https://doi. org/10.1002/9780470686652.eae444.

[12] Greene G., Friedrich P., Muir H. C., Wilson R. L., Thomas L. J., Very Large Transport Aircraft (VLTA) Emergency Requirements Research Evacuation Study (VERRES) - A Project Summary, "JAA Research Paper" 2003, 1.

[13] Cherry R. G. W. and Associates, A Study Analyzing the Trends in Accidents and Fatalities in Large Transport Airplanes, 2013.

[14] European Transport Safety Council (ETSC), Increasing the Survival Rate in Aircraft Accidents: Impact Protection, Fire survivability and evacuation, December 1996. 
[15] National Transportation Safety Board (NTSB), Safety Study Emergency Evacuation of Commercial Airplanes - PB2000917002 - NTSB/SS-00/01.

[16] Galea E.R., Wang Z., Jia F., Numerical investigation of the fatal 1985 Manchester Airport B737 fire, "The Aeronautical Journal" 2017, 121, 1237, 287-319, https://doi. org/10.1017/aer.2016.122.

[17] Civil Aviation Authority of United Kingdom (UK CAA), Flight Operations Bulletin - Cabin Safety, Notice to Air Operator's Certificate Holders - NATOCH Number 7/95.

[18] Orłowska I., Dziubiński M., Stochastyczny charakter procesu ewakuacji ludzi z budynków, BiTP Vol. 50 Issue 2, 2018, pp. 90-106, https://10.12845/bitp.50.2.2018.7.

[19] Cłapa I., Porowski R., Dziubiński M., Wybrane modele obliczeniowe czasów ewakuacji, BITP Vol. 24 Issue 4, 2011, 71-79.

[20] Kosiński R., Grabowski A., Matematyczne modelowanie i badania symulacyjne zachowania się ludzi podczas ewakuacji z budynków, „Bezpieczeństwo Pracy” 2013, 1, 20-25.

[21] Chattaraj U., Chakroborty U., Subhashini A., Empirical studies on impacts of obstacle inside corridor on pedestrian flow, „Procedia - Social and Behavioral Sciences" 2013, 104, 668-677, https://doi.org/10.1016/j. sbspro.2013.11.161.

[22] Ko S., Spearpoint M., Teo A., Trial evacuation of an industrial premises and evacuation model comparison, „Fire Safety Journal" 2007, 42, 91-105, https://doi.org/10.1016/j. firesaf.2006.07.001

[23] Engineering guide to human behaviour in fire, SFPE, 2003.

[24] Witryna internetowa: https://www.lot.com/pl/pl/dreamliner-787 [dostęp: 20.04.2020].

[25] Pathfinder 2011, instrukcja obsługi - wersja 2011.2, Thunderhead Engineering, Stigo.
LT. COL. MICHAL JASZTAL, PH.D. ENG. - graduated in 1999 at the Faculty of Electromechanics of the Military University of Technology in the field of Aviation. After completing his studies, he started working at the Institute of Aviation Technology of the Faculty of Electromechanics of the MUT and currently holds the position of assistant professor, conducting didactic classes and research. He is also the Head of the Team of Safety Engineering and Aircraft Armament and is the tutor of studies in the field of Safety Engineering.
PPŁK DR INŻ. MICHAŁ JASZTAL - ukończył studia w 1999 r. na Wydziale Elektromechanicznym Wojskowej Akademii Technicznej na kierunku Lotnictwo. Po ukończeniu studiów rozpoczął pracę w Instytucie Techniki Lotniczej Wydziału Elektromechanicznego WAT i obecnie zajmuje stanowisko adiunkta, prowadząc zajęcia dydaktyczne oraz prace badawcze. Pełni również funkcję Kierownika Zakładu Inżynierii Bezpieczeństwa i Uzbrojenia Lotniczego i jest opiekunem studiów na kierunku Inżynieria Bezpieczeństwa. 